\title{
THE DISINTERESTED THIRD STATE
}

\author{
Brainerd Currie* \\ Can you weigh a bushel of horsefeathers against next Thursday? \\ -Roger J. Traynort
}

\section{INTRODUCTION}

A generation ago-while I was in law school-Professor Joseph $\mathrm{H}$. Beale and the American Law Institute inflicted upon this country the Restatement of the Law of Conflict of Laws, a rigid, theoretical, and vastly oversimplified system for adjudicating the most complex problems that legal controversy has to offer. The feat was not accomplished without protest-notably from Professor Walter Wheeler Cook. Since then it has been the task of all but the most submissive courts and scholars to struggle against the overpowering influence of the established system and to formulate a different methodology, capable of yielding rational results in real cases. The success of these efforts has been in a sense remarkable, although the influence of the Restatement was always grossly disproportionate to its intellectual foundations. Today the Restatement stands renounced by the American Law Institute itself; no responsible scholar offers to defend it; court after court throws off the shackles without waiting for full development of a new rationale, increasingly without the obeisance to the old system that was ritually observed by pioneering rebels.

Demolition of the Restatement was by no means an easy task. At least one man, Professor Cook, may be said to have devoted his professional life to it. It was relatively easy, however, by comparison with the affirmative task of formulating a new method. It would be rash, indeed, for anyone to claim perfection of a new order. Yet the most remarkable thing about the revolt against the Restatement is the degree of progress that has been made toward a consensus as to the general outline that must be assumed by a new law of conflict of laws. This fact may escape the casual reader of modern critical comment. To such a reader it may well appear that the Restatement has been succeeded by nothing better than a gaggle of hostile factions, each claiming to have pre-empted the inside track in the race toward salvation. The common effort, if it can be called that, is indeed marred by pride of authorship, professional jealousy, and varying degrees of emancipation from the Influence; more than that, profound differences in individual conceptions of the nature, or function, of law and the institutions for its administration will for a long time to come prevent the promulgation of a comprehensive and detailed new system by any sort of academy-except, perhaps, that peculiar power structure, the

- William R.: Perkins Professor of Law, Duke University.

† Apropos of the weight to be accorded a presumption. Justice Traynor acknowledges his indebtedness to Prosser, Res Ipsa in California, 37 Calif. L. REv. 183, 225 (1949). Prosser in turn acknowledges his indebtedness to an unidentified English judge. 
American Law Institute. Nevertheless, something that looks like consensus is on the horizon; it is not true that a court disposed to turn its back on the frustrations of the discredited system must "voyage into... an uncharted sea."1

At this stage we certainly do not need a new Restatement, although we are threatened with one. Quite apart from what I believe to be the inherent futility of such an undertaking, deep-freezing seems hardly the indicated treatment for a discipline just emerging from its Ice Age. ${ }^{2}$ The American Law Institute has not in fact utilized the various streams of critical thought that have emerged in recent years. The Restatement Second embodies only a particular point of view, and one not distinguished for the degree of its emancipation. What American conflict-oflaws theory needs most at this stage is a real joinder of issues by the proponents of the new methodologies. One who presumes to offer a new technology in circumstances such as these should feel an obligation to evaluate carefully the efforts of others to the same end, and to work as harmoniously as possible toward a definition of differences, a reduction of misunderstanding, and the widest possible consensus.

It is easier to suggest such a procedure than to follow it. We are contentious people by profession, and not above disparaging our competitors' wares. Patient evaluation of the views of another is exacting and sometimes tedious work. The mechanics of confrontation are formidable; we have neither issue pleading nor pretrial conference to facilitate the process. Even a symposium such as this cannot bring about a satisfactory formulation of issues. The exchange of manuscripts, followed by revision of each in the light of the others, has repeatedly proved to be impracticable. By virtue of my access to the editorial offices, however, I have had the privilege of reading three manuscripts that were received before the deadline: those of Professors Cavers, Ehrenzweig, and Reese. I propose to take unfair advantage of this opportunity in the discussion that follows.

I shall not attempt to analyze these papers in detail in order to determine the degree of consensus and all the points of difference; the opportunity to read the manuscripts has not been adequate for that purpose, and, so far as Ehrenziweig is concerned, a review of his manuscript would not suffice. It would be necessary as well to review his recent treatise, which I have undertaken to do elsewhere. But I observe-perhaps wishfully-that a common element in these three papers is some concern with the method of governmental-interest analysis in some form-that is, with construction or interpretation of the respective rules of municipal law relating to a particular issue as a method of treating conflict-of-laws problems. Since my own belief is that the future of conflict of laws lies in the development of that method, I propose to explore briefly the question: How stands governmental-interest analysis as this symposium goes to press?

But only briefly. My original intention was to discuss a hitherto neglected problem encountered in the use of governmental-interest analysis: the problem of

${ }^{I}$ Shaw v. Lee, 258 N.C. 609, 616, 129 S.E.2d 288, 293 (I963).

${ }^{2}$ See Pearson v. Northeast Airlines, Ine., 309 F.2d 553, 557 (2d Cir. I962). 
the disinterested third state. Two of the manuscripts available to me give new importance to this problem. Hence the main purpose of this paper will be to explore it further. After all, what conflict-of-laws theory needs most, next to joinder of issue by the proponents of new methodologies, is further analysis of the difficult and obscure aspects of the respective methods.

Interest Analysis Up to a Point

A potential problem of conflict of laws is presented whenever it seems reasonably possible that a court may, on request or on its own motion, consider foreign law relevant for some purpose. It is important to observe that courts refer to foreign law for quite different purposes. For want of better terminology, these have been classified as (I) the purpose of finding a rule of decision and (2) all other purposes, including that of finding some datum made relevant by a rule of decision supplied by the law of the forum. ${ }^{3}$ We know too little about the second category to be confident that governmental-interest analysis in its present form would be entirely valid or adequate in application to the problems it presents. ${ }^{4}$ The papers under consideration are not concerned with that problem; they are concerned, as I have been primarily, with foreign law as source of the rule of decision. I shall therefore say no more than that all of us, and especially those who offer comprehensive Restatements and treatises, should be constantly aware of the different purposes of references to foreign law, and sensitive to the possible need for differences of treatment in consequence.

When it is suggested that foreign law is relevant as the source of the rule of decision, construction or interpretation of the laws of the respective states will reveal, in a significant number of cases, that although those laws may be different there is no real conflict because only one of the states has an interest in the matter. If conflict of laws had been defined as that branch of the law designed to deal with conflicts between the interests of two or more states in applying the policies embodied in their respective laws, no one would have treated these cases as raising problems in the conflict of laws. But when the subject was conceived as treating of all cases having contacts with a plurality of states having different laws, and when rules were devised for designating a particular contact as identifying the "governing law," false problems were created; and the solutions provided by the established system for such problems could be perverse in the extreme.

The clearest contribution of governmental-interest analysis to conflict-of-laws method is that it establishes the existence of such false problems and provides a workable means of identifying them. The method has been brilliantly employed by the New York Court of Appeals in Babcock v. Jackson ${ }^{5}$ to avoid application of the

${ }^{3}$ See Brainerd Currie, Selected Essays on the Conflict of Laws 66 et seq. (IgG3).

'See M. Traynor, Confict of Laws: Professor Currie's Restrained and Enlightened Forum, 49 CALIF. L. REv. 845, 873 (1961), suggesting that the method may be useful in this context but warning against abuse of the concept of the "datum" determined by foreign law.

${ }^{5} 12$ N.Y.2d 473 , 19I N.E.2d 279,240 N.Y.S.2d 743 (r963). 
guest statute of Ontario, the place of the tort, in an action between residents of New York. Cavers and I seem to be in complete agreement as to the effectiveness of the method in this sector. ${ }^{6}$ Reese approves the result of Babcock v. Jackson, speaking in terms of the state of "dominant interest," though he appears to prefer his own method of determining the state having the "most significant relationship." Ehrenzweig also approves that result, and emphasizes that the New York court implemented the "most significant relationship" formula of the Restatement Second with a weighing of state "interests." But he also emphasizes that his conception of governmental-interest analysis, or inquiry into the policy of laws, is very different from mine. ${ }^{9}$ We shall have to wait for his forthcoming comment in the Columbia Law Review for a fuller statement of his views on Babcock v. Jackson. His differences with me as to governmental-interest analysis in general are too subtle for treatment in the space available here. The best key to understanding of his position, however, is that, whatever validity he concedes to that analysis, he subordinates it to what he calls "true rules" for choice of law, including a "basic rule of validation."10 For reasons that do not correspond in all respects, Reese and I have difficulty in accepting that particular "true rule," at least. ${ }^{11}$

In other cases analysis may at first indicate an apparent conflict of interests; specifically, it may be clear that if the forum were to assert an interest in the application of its policy, it would be constitutionally justified in doing so. But no principle dictates that a state exploit every possible conflict, or exert to the outermost limits its constitutional power. On the contrary, to assert a conflict between the interests of the forum and the foreign state is a serious matter; the mere fact that a suggested broad conception of a local interest will create conflict with that of a foreign state is a sound reason why the conception should be re-examined, with a view to a more moderate and restrained interpretation both of the policy and of the circumstances in which it must be applied to effectuate the forum's legitimate purpose. An analysis of this kind (according to my thinking, which again is perhaps wishful) was brilliantly performed by Justice Traynor in Bernkrant v. Fowler. ${ }^{12}$ The policy of the California statute, of which there was no counterpart in Nevada, was to protect decedents' estates from false claims based on alleged oral contracts to make wills. That policy might reasonably be said to extend to all estates being administered in California, especially those of local domiciliaries. No constitutional

\footnotetext{
${ }^{6}$ Cavers, supra 732, at 733.

${ }^{7}$ Reese, supra 679, at 688-89. Cf. his discussion of an earlier false-problem case, Grant $v$. McAuliffe, in Restatement (SECOND), CoNFict of LAws $\$ 390$, at 123 (Tent. Draft No. 8, 1963). This is at any rate a considerable advance over his former position: "Speaking generally, each tort is composed of two essential elements: defendant's conduct and plaintiff's injury. Where both of these elements are grouped in a single state, as is true in the vast majority of cases, there is obvious reason for applying the law of that state." Cheatham \& Reese, Choice of the Applicable Law, 52 Corum. L. REv. 959, 976 (1952).

${ }^{B}$ Ehrenzweig, supra 700, at 702 n.I5.

'Ibid. See also Ehrenzweig, Choice of Law: Current Doctrine and True Rules, 49 Calir. L. Rev. 240, 243-48 (I961); Albert A. EhreNZWEIG, CoNflict OF LAWS $\$$ I22 (I962).

${ }^{10}$ EirRenzweig, op. cit. supra note 9, § I75 et seq.

${ }^{11}$ Recse, supra 679, at 698 .

${ }^{12} 55$ Cal.2d 588, 12 Cal. Rptr. 266, 360 P.2d 906 (196r).
} 
principle would be offended by such an application. But Justice Traynor, considering all the circumstances, concluded that no such broad application was necessary to effectuate the legislative policy. He therefore declined to apply the California statute, thus avoiding conflict with Nevada law and policy.

So far as I know, everybody except the losing party is delighted with the result in Bernkrant v. Fowler. Since the law of the place of contracting was applied, Professor Beale himself would have approved. In the reasons for the result there is something to comfort each of the contending camps but triumphant satisfaction for none. Although the reasoning is foreign to everything in Beale's philosophy, he would not, I think, have been crushed by the rejection; for when his life's work was done he "humbly and modestly ... forecast a movement of social-economic thought" calculated to produce just such reasoning. ${ }^{13}$ Since the law applied was that which gave validity to the contract, to the accompaniment of references to the expectations of the parties, Ehrenzweig may well applaud. ${ }^{14}$ Supporters of the Restatement Second may be pleased because it may be said, though the opinion does not use the formula, that the law applied was that of the state having the "most significant relationship," and that proposition cannot be objectively refuted-any more than it can be objectively demonstrated. That is not quite Reese's position in this symposium, as we shall see. I find the opinion congenial because it speaks in terms of governmental interests and because the method is explicitly that of statutory construction. Those who accept the basic premises of governmental-interest analysis but insist that the court be free to "weigh" and choose between the conflicting interests may feel that the opinion must be interpreted as just such a weighing operation. This may be close to Cavers' position, though in this symposium he does not discuss the case directly.

Pausing only to remark that the high degree of agreement on result coupled with the low degree of agreement on reasons is characteristic of the present state of conflict-of-laws thinking, ${ }^{15}$ let us leave this discussion suspended in mid-air and proceed to a third type of case: Analysis reveals a conflict of interests that cannot be avoided despite reconsideration with the utmost good will and moderation. From the point of view of each state, application of its law in the circumstances is required for the effectuation of governmental policy. What is the court to do now? I have suggested that the law of the forum should be applied. It is no part of the duty of a court to subordinate domestic interests to those of a foreign state. The conflict must remain unresolved, unless it can be resolved by political action. Resolution of a conflict between the interests of co-ordinate states is a function of a high political order, which courts are not equipped to perform.

This has been an unpopular suggestion. Probably no unqualified acceptance of

${ }^{13}$ Beale, Social Justice and Business Costs-A Study in the Legal History of Today, 49 Hanv. L. Rev. 593, 609 (1936).

${ }^{14}$ Sec Ehrenzweig, op. cit. supra note 9, at 475.

${ }^{25}$ Partisans who regret the pluralism of avant-garde opinions such as this should remind themselves that a justice of the California Supreme Court must win the votes of at least three of his brethren if his opinion is to prevail. In Bernkrant Traynor got all six. 
it can be cited. At one time it loomed as the most controversial aspect of governmental-interest analysis. So far as I am concerned, however, it lost most of its controversial character and most of its interest some time back. Cavers says: ${ }^{10}$

... Currie seems to me to invite the judiciary to perform essentially the same function he would forbid when he would allow a court in State $F$ to take into account the policy of State $X$ in determining whether the forum's policy should be considered in conflict with it, presumably in a situation where, but for the State $X$ policy, the forum's law would be applied.

I made the same criticism myself two years ago, reformulating one voiced by Professor Alfred Hill. ${ }^{17}$ I conceded its validity. I went on, however, to argue that though the function is essentially the same, there is an important difference between a court's construing domestic law with moderation in order to avoid conflict with a foreign interest and its holding that the foreign interest is paramount. When a court avowedly uses the tools of construction and interpretation it invites legislative correction of error-or at least criticism from the law reviews. When it weighs state interests and finds a foreign interest weightier it inhibits legislative intervention and confounds criticism.

To illustrate how the weighing process might work, Cavers suggests a variation on the facts of Grant v. McAuliffe: ${ }^{18}$

... [S] uppose a motorist from Arizona had died after injuring a Californian in California, and the victim sued the motorist's estate. There is, to be sure, a rational basis for application of the Arizona policy that personal injury actions abate upon the death of the tort-feasor. However, the greater interest of California in applying its policy of nonabatement to the injury of a person on its highways by an out-of-state user of those highways seems to me not only clear but susceptible of generalization into a workable rule, a rule which, one might hope, would be recognized in Arizona as well as in California. If one were to say that there is no "true conflict" in such a case, the effect would be only to convert the concept of "false conflict" from a premise into a conclusion.

What is clear to me is that Arizona could reasonably and commendably allow recovery in such a case by means of a moderate and restrained interpretation of Arizona's policy and interest, such as was accomplished in Bernkrant v. Fowler. But what is gained by casting such a decision, instead, in terms of the "greater" interest of California? Further, what is gained by projecting such a decision into a generalized rule for choice of law? Why is not the Bernkrant technique sufficient? Before we resort to shopworn talk of uniformity, simplicity, predictability, and so on, let us face the fact that the rightness of such a decision is not self-evident; it may not be so clear to others as it is to Cavers and to me; and it is to others, not to us, that the responsibility of decision has been committed. Cavers has only hinted at his reasons for believing that the interest of California is the greater. Is it

${ }^{10}$ Cavers, supra 732, at 734 n.9.

${ }^{17}$ See Currie, The Verdict of Quiescent Years, 28 U. Cur. L. Rev. 258, 275 (I96I), op. cit. supra note 3, at 604 .

${ }^{18}$ Cavers, supra 732 , at 733 n.4. 
because compensation for personal injury ranks higher than the expectations of heirs in the scale of Values? That is not so in the internal polity of Arizona. Is it because the rule of abatement is archaic and inhumane? Arizona does not so consider it. Is it because the deceased tortfeasor probably had liability insurance, so that those interested in the estate will not in fact suffer? If so, that circumstance might well be brought into the open. Is it because the State of California itself, in its corporate capacity, may suffer the burden of caring for the injured victim? The possibility furnishes an undoubted basis for California's assertion of an interest in the application of its survival rule; but we must admit that the interest is a conventionalized one. In a particular case there may be no possibility of such a burden. ${ }^{10}$ Is it because in using the highways of California the tortfeasor "consents" to be bound by her laws?20 I trust not. Suppose the victim is felled in California by a stray bullet from the rifle of an Arizona deer hunter. If California's interest is indeed the greater in the highway case, I should not adjust easily to its becoming the lesser when the highway element is subtracted, even though the hunter remains well within Arizona territory.

It is at least conceivable that the Arizona legislature might view with displeasure the decision of an Arizona court giving primacy to the interest of California. Is it possible that the advocates of judicial weighing of state interests actually want to inhibit corrective action by the legislature? That would be the tendency of a decision cast in terms of greater and lesser interests. There appear to be just two reasons $^{21}$ why one might prefer this type of decision to one of the Bernkrant type, cast in terms of construction and interpretation: (I) the tendency to inhibit legislative correction is positively desirable; and (2) it would be far easier to construct generalizations on the basis of interest-weighing decisions that of ad hoc decisions purporting to do no more than construe domestic law in the light of the circumstances of a particular case. Thus interest-weighing decisions encourage the hope that in the course of time it may be possible to construct a Restatement on entirely new principles.

The second reason is the one suggested by Cavers; but I fear that the first cannot be ruled out as a motivation of those who insist on weighing interests-especially since the anticipated generalized rules, under the imprimatur of the American Law Institute, would powerfully reinforce the tendency to inhibit. Distrust of the legislative process, particularly with reference to questions of conflict of laws, characterizes much of the literature of the subject: this is a job, the idea is, that the courts can do better. ${ }^{22}$ When the focus is on the powers of Congress under the

${ }^{19}$ See Carroll v. Lanza, 349 U.S. 408 (1955).

${ }^{20} \mathrm{Cf}$. Hess v. Pawloski, 274 U.S. 352 (1927).

21 This leaves out of account a third reason, suggested by Recse's paper, that will be discussed in Part II, infra: An interest-weighing analysis may be preferable from the standpoint of the disinterested third state.

${ }^{22}$ See EHrenzweig, op. cit. supra note 9, at 350; Cavers, supra 732, at 752-53; Hill, Governmental Interest and the Conflict of Laws, 27 U. Cen. L. Rev. 463,475 (1960). 
full faith and credit clause ${ }^{23} \mathrm{I}$ am in complete agreement with the almost unanimous consensus that there should be legislative intervention only on an ad hoc basis, and only when the need for uniformity of result in a specific context is clearly demonstrable. But if there is an implication that courts rather than state legislatures should predominantly determine the reach of state policy and interest, I submit that the implication is radical and wrong. On one plane of discourse, to be sure, it is easy to be cynical about the contribution that can be made to problems of conflict of laws by the state legislative bodies to which we have entrusted our fate, and even reading the Congressional Record can be depressing. But our system of government invests such bodies with power to make laws for the expression of governmental policy, and to define the scope of governmental interests. Even if I were convinced that courts were better equipped for the task I could not acquiesce in their assumption of it; and on occasion I have been disillusioned even with courts, and even with law professors, and even with Institutes. Therefore, while I agree with Cavers that the Arizona court might commendably defer to California's interest in his variation of Grant v. McAuliffe, I would earnestly hope it would do so in the becoming fashion of the Bernkrant case: in the exercise of its undoubted power to interpret the laws, subject to the revisory power of the legislature, rather than in the exercise of some oracular power to pronounce immutable truth in metaphorical terms.

Reese disagrees. For him the function required of the court is not even that of "appraising the governmental interests of each jurisdiction, and turning the scale of decision according to their weight," 24 but that of delicately balancing ten "choice-oflaw policies," only one of which is directly concerned with the purposes of the particular rules of law involved. ${ }^{25}$ Using Bernkrant v. Fowler for illustrative purposes, Reese says there are two ways for the court to proceed: One is ${ }^{26}$

to admit frankly that it has the power of decision and then to inquire whether the value of furthering the purposes sought to be achieved by the statute is outweighed in the particular case by other choice-of-law policies and by the policies of other states. This was the approach taken by Justice Traynor.... In effect, therefore, Justice Traynor held that the policies underlying the California Statute of Frauds must bow before the choiceof-law policies (a) of protecting the justified expectations of the parties; (b) of applying the law of the state of dominant interest; and (c) of upholding the fundamental policy underlying the local law field involved, which, in the case of contracts, is to uphold contractual obligations assumed in good faith.

The other, which will lead to the same result, is for the court to "pretend" that its task is one of statutory construction. For Reese statutory construction is equated with an inquiry into whether "the legislature did or did not intend to have the statute applied to the particular state of facts." Since everyone knows that the legislature

${ }^{23}$ U.S. Const. art. IV, $\S \mathrm{I}$.

24 Alaska Packers Ass'n v. Industrial Acc. Comm'n, 294 U.S. 532, 547 (I935) (Stone, J.).

${ }^{25}$ Recse, supra 679, at 682. It seems significant that the reporter for the Restatement Second has not changed his basic philosophy of conflict of laws in the last eleven years.

${ }^{20}$ Recse, supra 679, at 685-86. 
never thought about the factual configuration presented by the case at bar, the judges of necessity must inquire what the legislature would have desired had it thought about the problem; and this inevitably means that the judges will decide the case according to the same choice-of-law policies that are employed in the first process. "The only difference is that a court following the first approach will frankly state that it is making the decision, while a court that adheres to the second approach will pretend to be effectuating the intentions of the legislature."27

The charge that the latter process is a pretense is an indictment of all statutory construction; for the process of determining the territorial scope of a statute differs from that of determining its temporal scope, or its application to marginal domestic situations, only in that the interest of another state is a factor to be taken into account. But those who believe that problems in the conflict of laws are appropriately treated as problems of statutory construction (or of the interpretation of common-law rules) are not likely to lay down their cause in dismay because of Reese's insight into the fictive character of legislative "intent." That insight is older than the first Restatement. ${ }^{28}$ Reese is not unaware that 'The phrase, 'legislative intention,' may be taken to signify the teleological concept of legislative purpose, as well as the more immediate concept of legislative meaning," ${ }^{20}$ since his fourth choice-of-law policy enjoins consideration of the purpose of the relevant rule of local law. Granting all the difficulties that statutory construction, or the ascertainment of legislative purpose, involves, it is difficult to understand what progress is made by burying that process in a welter of vague and contradictory principles for choice of the "applicable" law. That the preference for this multifarious approach is based on distrust of the legislature is suggested, despite the deference expressed in the first choice-of-law policy, by Reese's insistence that the court "admit frankly that it has the power of decision." ${ }^{30}$ That is, the court should go beyond anything that can rationally be described as statutory construction, appealing to "policies" some of which can by no stretch of the imagination be attributed to the legislature; and the court should emphasize its "power" to decide in this way. Certainly no such judicial conceit can be attributed to the decision in Bernkrant v. Fowler. Of course the legislature had not addressed itself to the precise problem; ;1 of course the court had to legislate in order to decide. It did so, however, in such a way as to invite legislative correction of its interpretation of the legislative purpose-not in such a way as to give the

${ }^{27}$ Id. at 686.

${ }^{28}$ See Radin, Stattuory Interpretation, 43 Harv. L. Rev. 863 (1930), and the reply by Landis, $A$ Note on Statutory Interpretation, 43 HARv. L. Rev. 886 (1930); cf. Symposium on Statutory Construction, 3 VAND. L. REv. 365 (1950).

${ }^{20}$ Jones, Statutory Doubts and Legislative Intention, 40 CoLun. L. Rev. 957, 972 (1940); Landis, stspra note 28, at 888. "... [T] he principle that courts are bound to follow 'legislative intention' has been taken to mean that in determining the effect of a statute in cases of interpretative doubt, the judge should decide in such a way as will advance the general objectives which, in his judgment, the legislators sought to attain by enactment of the legislation." Jones, supra at 973 .

${ }^{30}$ Reese, supra 679, at 685 .

${ }^{81}$ Cf. Richards v. United States, 360 U.S. I (1962). 
impression that the result was dictated by principles having a validity independent of legislative purpose. ${ }^{32}$

Differences in terminology, or modes of statement, account for a good part, though by no means all, of the disagreement among the present generation of critics. For example, though I object to Reese's system for choice of law as he has stated it, I would hardly deny that among his ten choice-of-law policies there are factors appropriately taken into account by a court in the process of construction and interpretation. Cavers has a special point about terminology, apparently aimed in my direction. I concede its validity, and hope thereby to enlarge the area of agreement.

It will be recalled that the concluding sentence in his comment suggesting that Arizona might well defer to the interest of California in his hypothetical variant of Grant v. McAuliffe was: "If one were to say that there is no 'true conflict' in such a case, the effect would be only to convert the concept of 'false conflict' from a premise into a conclusion." ${ }^{33}$ In this paper I have mentioned three classes of cases: (I) Those in which analysis indicates that only one state has an interest in the application of its policy; (2) those in which it appears that each state would be constitutionally justified in asserting an interest, but on reflection conflict is avoided by a moderate definition of the policy or interest of one state or the other; (3) those in which a conflict of interests persists despite efforts to avoid it by moderate definition of policies and interests. In the past I have enjoyed saying that the problems of conflict of laws consist of (I) false problems and (2) problems that cannot be solved except by political action. That mode of statement served to dramatize the attack, in terms of governmental interests, on the traditional system of rules for choice of law typified by the old Restatement..$^{34}$ Rather plainly, however, it is not helpful to speak of cases of the second class as "false problem" cases. Bernkrant v. Fowler (like the Cavers variant of Grant v. McAuliffe) was a case in which the forum state could reasonably assert an interest in the application of its law and policy; it was only after painstaking analysis that the court could say, because of its delimitation of local interests, that

Since there is thus no conflict between the law of California and the law of Nevada, we can give effect to the common policy of both states to enforce lawful contracts and sustain Nevada's interest in protecting its residents and their reasonable expectations growing out of a transaction substantially related to that state without subordinating any legitimate interest of this state. ${ }^{35}$

s2 "The judge, when he must act as a law-maker to fill in the gaps of a statute, exercises not original legislative power but delegated power, comparable to that conferred upon administrative officers possessed of rule-making or subordinate legislative authority." Jones, supra note 29, at 973. "But the insistence of ... [a science of statutory interpretation] must be that judicial legislation shall concern itself only with the interstitial tissues of the body politic and not its gristle." Landis, supra note 28 , at 893 .

${ }^{28}$ See text at note 18 supra.

34 I do not mean to say that I used this classification solely because of its rhetorical shock effect. There is, unfortunately, such a thing as limited insight. In my earlier writings I concentrated the analysis on a hypothetical state that could be counted on to assert its interests to the constitutional limit. See Currie, op. cit. supra note 3 , at 6 I6. In consequence, the "restrained and cnlightened forum" was relatively neglected.

${ }^{3 s}$ Bernkrant v. Fowler, 55 Cal.2d at 596, r2 Cal. Rptr. at 270, 360 P.zd at gro. 
Such a case does present a problem in the conflict of laws until such time as the court has brought to bear all the skills available for the solution of such problems.

Indeed, the three classes of cases are a continuum with no clear internal boundaries. Even the first class appears initially to present a problem in the conflict of laws. When Grant v. McAuliffe was decided in 1953 it would have occurred to few people-certainly not to me-to suggest that it did not present such a problem. Before it can be identified as a false-problem case it must be approached in terms of governmental-interest analysis (or perhaps in terms of Reese's ten policies ${ }^{30}$ ) and a careful analysis must be made of the respective policies and interests. Another case of this class, Babcock $v$. Jackson, ${ }^{37}$ would be transformed into a case of the second or third class if our information as to how liability insurance premiums are calculated were different-yet the bearing of this information would not be apparent to all observers at first sight. ${ }^{38}$ For the time being I shall continue to speak of cases of the first class as false-problem cases, meaning that, after adequate analysis, reasonable men can hardly differ on the proposition that only one state has an interest in the application of its policy. But in cases of the second class reasonable men may differ as to whether a conflicting interest should be asserted, and so a real problem is presented. I continue to regard cases of the third class as real and intractable problems; in them, after careful analysis, reasonable men will tend to agree that neither court can, with fidelity to the interest of its own state, defer to the interest of the other. Kilberg $v$. Northeast Airlines ${ }^{30}$ appears to be such a case.

II

\section{The Disinterested Third State}

\section{A. The Problem and Its Importance}

In cases of the third class, where the interests of two states are clearly in conflict, the obvious, sensible, and constitutional course is for the forum to apply its own law. But what if the forum state is disinterested, and the conflict is between two other states? Specifically, how would the Kilberg case be decided by a court of Connecticut or Rhode Island? Choice between the competing interests of co-ordinate states is a "delicate" and "refractory" problem ${ }^{40}$ which even the United States Supreme Court, in constitutional cases, has on the whole commendably avoided.11 It is a task appropriately to be performed by higher political authority, or by diplomats. ${ }^{42}$ Yet it cannot always be avoided by the courts. The disinterested third state cannot avoid the problem as the Supreme Court can. When the Supreme

${ }^{80}$ But see Restatement (Second), Conflict of Laws $\$ 380$, at 123 (Tentative Draft No. 8, r963).

87 Note 5 supra.

${ }^{38}$ See Currie, Comment, 63 Colum. I .Rev. I233 (1963).

${ }^{39} 9$ N.Y.2d 34,172 N.E.2d 526, 211 N.Y.S.2d 133 (196I).

10 Watson v. Employers Liab. Assur. Corp., 348 U.S. 66, 75-76 (r954) (Franlfurter, J., concurring).

${ }^{2}$ See Currie, op. cit. supra note 3 , ch. 5 .

${ }^{22}$ Cf. McCulloch v. Sociedad Nacional de Marineros, 372 U.S. yo (1963); Incres S.S. Co. v. International Maritime Workers Union, 372 U.S. 24 (1963); D. P. Currie, Flags of Convenience, American Labbr, and the Conflict of Laws, 9663 Sup. Cr. Rev. 34 . 
Court avoids the problem in reviewing state-court decisions it leaves the conflict unresolved, but the case is decided. The disinterested third state must solve the conflict somehow in order to decide the case. ${ }^{43}$

The theoretical possibility of such a problem becomes apparent as soon as the problems of conflict of laws are formulated in terms of governmental interests. ${ }^{44}$ How serious the problem is as a practical matter it is difficult to say. In the visible experience of modern American law teachers its occurrence is extremely rare. Our casebook cases, and the current cases about which we write in the law reviews, almost invariably involve a conflict, or apparent conflict, between the forum and another state. It is extremely difficult to find actual cases for the purposes of a discussion such as this. ${ }^{45}$ For that reason I have tended to regard the problem as relatively unimportant, though intellectually troublesome, and have even been disposed to be facetious about it. ${ }^{46}$ On the other hand, Max Rheinstein once remarked to me that this problem is a central focal point of continental conflict-oflaws theory. It seems difficult to reconcile this proposition with the continental concept of judicial competency, or jurisdiction, which tends to insure that the forum will have some relationship to the case such as to make its own law appropriately applicable. ${ }^{47}$ Yet my colleague Hans Baade tells me that in his experience as an associate of a university institute, writing opinions on foreign law for the German courts, a substantial number of cases involved conflict not between German and foreign law but between foreign laws. ${ }^{48}$

Whatever the practical dimensions of the problem have been, two papers in this symposium seem to give it new importance. First, Reese tells us that this is the very problem with which the Restatement deals: ${ }^{49}$

... [T] The Restatement is written from the viewpoint of a neutral forum which has no interest of its own to protect and is seeking only to apply the most appropriate law. This approach is taken for the reason among others that some of the considerations that will induce a court to apply its own local law rather than that of another state are many and varied and are not susceptible to restatement. It can, of course, be said in criticism that cases rarely arise in truly neutral forums. This may well be true. Yet the fact remains that the approach adopted appears to be the only practicable one. Also even an interested

${ }^{13}$ Currie, op. cit. stipra note 3 , at 273-74.

"See id. at 120-2r.

4 Walton v. Arabian Am. Oil Co., 233 F.2d 541 (2d Cir. 1956), cert. denied, 352 U.S. 872 (1956), is not such a case since no foreign law was appropriately brought to the attention of the court. See Currie, op. cit. supra note 3 , at 3,62-64. Youssoupoff v. Widener, 246 N.Y. 174, 558 N.E. 64 (1927), may be such a case.

${ }^{10}$ Sec Currie, op. cit. supra note 3 , at I2I, 609.

"7 Albert A. Ehrenzweig, Conflict of Laws i, 73 n.12 (1962).

${ }^{8} \mathrm{Cf}$. Baade, The Netherlands Private International Law of Succession and the German Courts, 1959 Nederiands TiJdschirift voor InTERnationaI Recht 174. Further on the frequency of the problem compare M. Traynor, Conflict of Laws, 49 CALIF. L. Rev. 845, 866-67 (196I), with Hill, Governmental Interests and the Conflict of Laws, 27 U. CHI. L. Rev. 463, 504 (1960); and see De Nova, infra 808, at 820-21.

"Should not perhaps conflicts thinking start with that very hypothesis of a case pending in' the courts of a state with which the case has no contact other than that of being the state of litigation? Many problems might be clarified if we were to start on that assumption. Such a state's courts need guidance. What should it be?" Rheinstein, How to Review a Festschrift, II AM. J. CoMp. Law 632 (I962).

${ }^{40}$ Reese, supra 679, at 692-93. 
forum will usually be guided by what it conceives to be correct rules of choice of law. Somewhere it will be made clear in the final version of the Restatement that the court of an interested state will depart from the rules stated in obedience to an express legislative mandate and on occasion, in the absence of such a mandate, in order to further an important local policy.

This is a remarkable statement. It comes as news to me, as I believe it will to other students of the subject. I have reviewed the original Restatement and the tentative drafts of the Second without finding any reference to this limited point of view. Certainly the Restatement in all its forms has tended to convey the impression that it dealt with the whole of the subject, or at least with those problems that loom largest in our experience. The approach is not only limited but strangely inverted. We are to select as our model the rare and difficult situation in which a disinterested forum is confronted with a conflict between the laws of other states; we are to find "correct" rules for choice of law in this situation; and we are to indulge the hope that these rules will be applied even in the normal situation in which the forum is interested-except "on occasion," to further an "important" local policy. If this indeed is, and has been, the point of view from which the Restatement is written, we are provided with dramatic proof of the tendency of rules for choice of law, devised originally for a limited and perhaps legitimate purpose, to burst out of the intended bounds and swallow up the whole universe of choice of law. If the limited purpose stated by Reese had been proclaimed from the beginning the history of the first Restatement might have been different. The black-letter rules might have served well enough for the rare and difficult case of the neutral forum, or disinterested third state, in which any choice of law must be to a degree arbitrary. Perhaps if the limited purpose is blazoned on the cover of the Restatement Second in large type those of us who are apprehensive about the effect of that project can relax. But this, of course, is only a dream: it seems clear enough that the genie cannot be kept in the bottle. Indeed, Reese makes it clear enough that he has no desire to keep it there. He wants to devise rules for Almost-Never Land with the expressed hope that they will encroach on real life and be applied to the neglected cases that make up our normal experience.

Second, Cavers proposes (along with Professors Richard H. Field and Paul J. Mishkin, reporters for the American Law Institute's Study of the Division of Jurisdiction between State and Federal Courts) the deliberate creation by act of Congress of new occasions for the phenomenon of the neutral forum. ${ }^{50}$ This is an arresting

\footnotetext{
so This is a purposely brief statement of the proposal, designed to emphasize its relationship to the subject of this paper. The reader who has not already read Cavers' own statement of it is admonished that the proposal is carefully limited to two highly specialized classes of cases, as will be noted in due course below.

Having read this article in galley, Mr. Cavers informs me that I have cast him in a role he did not fill and, in so doing, have done an injustice to the roles of Messrs. Field and Mishkin. See Cavers, supra 732 n.I. This regrettable over-emphasis of Mr. Cavers' role in the STudy is no doubt attributable to my enthusiasm for the rare opportunity of commenting on other papers appearing in this symposium. It is too late to correct the several attributions of the Institute proposals to Cavers, but I offer my apologies to Messrs. Field and Mishkin.
} 
proposal, since I have thought that the problems presented by that phenomenon are so difficult that it ought to be avoided whenever that is reasonably possible. The deliberate creation of what appears to be a dilemma requires strong justification.

\section{B. Avoidance of the Problem by Dismissal}

Indeed, I venture to repeat here as my first conviction concerning the problem of the disinterested third state something I have said before: in general, the problem should be avoided if possible. A court presented with a conflict between the laws of two other states, no interest of the forum state being apparent, should dismiss on forum non conveniens grounds if that is consistent with justice. This conviction arises, of course, from my belief that true problems of conflict of laws are problems of conflicting interests of co-ordinate states, and that a court is ill-equipped to resolve such conflicts, except as in so doing it furthers the interests of the state that created it. If I am right in assuming that the Kilberg case presents a true conflict of interests between New York and Massachusetts the course to be followed by the courts of those states is clear: New York courts will apply New York policy and Massachusetts courts will apply Massachusetts policy. But if that action for wrongful death had been brought in Connecticut the courts of that state would have been confronted with a baffling problem. ${ }^{51}$ It is not necessary to agree with my provisional view that the problem is well-nigh insoluble on any wholly satisfactory basis to agree that Connecticut might well avoid it, remitting the plaintiff to a more appropriate forum of his choice. ${ }^{52}$ Of course such a disposition will not always be appropriate. It is axiomatic that the doctrine of forum non conveniens is an "instrument of justice," be dismissed unconditionally-if, for example, the action was timely commenced under the laws of all three states, but would be time-barred if it must be commenced anew in New York or Massachusetts. This and other situations in which dismissal would be inappropriate (theoretically they might be numerous) account for the problem of the disinterested third state.

What has been said here does not by any means dispose of the Cavers proposal. In the first place, the view that the plight of the disinterested forum is disagreeable is a personal one; I can conceive of a quite different predilection, according to which

"I assume here that the defendant would be amenable to process in the forum state, but that the circumstances supporting the exercise of jurisdiction (e.g., doing business) do not give that state any interest in the application of its domestic policy.

"If the action should be brought in a federal court in Connecticut this solution apparently would not be available, since 28 U.S.C. $\$ \mathrm{I}_{404}(\mathrm{a})$ substitutes transfer for dismissal where transfer is possible. Hence the court could not remit the plaintiff to an appropriate forum of his choice but must, in ordering transfer, in effect determine the outcome. This is a reason why it might be constructive if $\S I_{4} 0_{4}$ (a) were amended, as $\S$ I 406 (a) has been amended, to allow dismissal as an alternative. See CurRIE, op. cit. supra note 3 , at 439-40. The American Law Institute's tentative proposals concerning the transfer section provide for a stay to permit resort to a state court where no available federal forum is convenient, thus apparently contemplating conditional dismissal. AMERICAN LAw INSTITUTE, STUDY oF the Division of JuRisdiction between State and Federal Courts $\$ 1306$ (a), (b) (Tent. Draft No. I, 1963) [hereinafter cited as Study of JuRisdiction]. But this provision is too limited for the purpose underlying my suggestion.

${ }^{83}$ Cardozo, J., dissenting in Rogers v. Guaranty Trust Co., 288 U.S. 123, I5I (1933). 
such a situation would be the ideal context of adjudication. In the second place, I am here stating only a general attitude, acknowledging the possibility that resort to a disinterested forum may in some situations be preferable to the possible alternatives. From my point of view, however, one who proposes deliberately to set up the neutral forum has the burden of proof. Whether Cavers and his associates have discharged that burden in connection with their proposal remains to be seen.

\section{Avoidance of the Problem by Construction}

A second firm proposition concerning the problem may be stated: a court confronted with an apparent conflict between the laws of two other states should, before resigning itself to the difficult task of choice, make sure that the conflict is a real one. Thus if an action parallel to Babcock $v$. Jackson were now to be brought in a state other than New York or Ontario the result should be clear: there being no conflict of interests, the law of the only interested state, New York, should be applied. One may hope that the same kind of analysis can be applied to cases of the second class: careful consideration may lead to the conclusion that, though either state might constitutionally assert an interest in the application of its policy, the respective interests may be construed moderately, in such a way as to avoid conflict. This may be asking a good deal of the neutral forum, and, to be sure, its moderate definition of the interests of other states cannot be authoritative. But the mere fact that another state is involved is no bar to such analysis; in the more normal case a court must determine the interest of the foreign state as well as that of its own.

Bernkrant v. Fowler is not readily adaptable for purposes of the present discussion, since a suit to enforce a promise to make a will is not likely to be brought in a disinterested forum. By hypothesis the forum in such a case is either the domicile of the decedent or the situs of property under administration; and in either case the forum might conceivably assert, and would be constitutionally justified in asserting, an interest in applying its requirement of a writing. If the action is brought in a state where there is only ancillary administration, and if the court is of the opinion that domestic policy is only for the protection of local domiciliaries, the problem is presented; and the forum might well reach the result reached by California itself in choosing between the laws of California and Nevada. Certainly it should reach that result now that the Bernkrant decision is on the books; conceivably it might have done so as an original matter, given some of the judicial skills of a Traynor. An analysis of just this sort has recently been brilliantly performed by Judge Roszel C. Thomsen, of the United States District Court for the District of Maryland. Actual cases in which the forum is disinterested are hard to find; study of Judge Thomsen's decision ${ }^{54}$ should be more rewarding than analysis of a hypothetical variant of the Bernkrant case.

In February, Ig60, a collision occurred in North Carolina between a station

${ }^{64}$ LaChance v. Service Trucking Co., 215 F. Supp. 162 (D. Md. 1963). 
wagon and a tractor-trailer. The driver of the station wagon, Mr. LaChance, and his wife, a passenger, both of whom were injured, were citizens of Maine. The owner of the tractor-trailer was a Maryland corporation. Mrs. LaChance brought an action against the corporation in the district court in Maryland, based on diversity of citizenship. The corporation filed a third-party complaint against the husband on the theory that he was a joint tortfeasor, liable for contribution in the event the corporation should be found liable. Mr. LaChance (who was plaintiff in a separate action against the corporation) moved to dismiss the third-party complaint. ${ }^{65}$

The following propositions were not controverted:

I. It is a general rule, almost universally recognized, that a right to contribution can arise against a joint tortfeasor only if he is himself directly liable to the injured party. In support of this proposition Judge Thomsen could cite cases from both Maryland and Maine; it was assumed, no doubt correctly, to state the law of North Carolina as well.

2. North Carolina permits a wife to sue her husband for personal injuries, and allows contribution between joint tortfeasors.

3. Neither Maryland nor Maine permits a wife to recover damages for personal injuries from her husband, and neither would permit the husband to be impleaded for purposes of contribution. ${ }^{56}$

Since the case was in the federal court by virtue of the diversity jurisdiction, and concerned state-created rights, the court felt bound by the Klaxon ${ }^{57}$ rule to follow Maryland's rules for choice of law. No Maryland cases precisely in point being available, Judge Thomsen had to decide as he thought a Maryland court would decide the novel question. The convenience of the forum was considered: a motion by the defendant to transfer to North Carolina was denied without opinion. ${ }^{58}$ The reasons for the denial are not difficult to imagine. An action brought against a corporation in the state of its creation is ordinarily not one to be dismissed or transferred on the basis of considerations normally associated with the doctrine of forum non conveniens; and the special considerations suggested for the case of the disinterested forum are inapplicable here, if only because transfer to North Carolina

t5 The statement of facts is based in part on the earlier opinions reported in 208 F. Supp. 656 (D. Md. I962) and 215 F. Supp. 159 (D. Md. 1963), and has been somewhat simplified. There were other injured passengers in the station wagon, another defendant, and another third-party defendant; but these complications can be omitted without prejudice to discussion of the main problem.

${ }^{50}$ For present purposes I assume that the denial of the right to implead in these states is based on proposition No. $I$ in the text above, rather than on rejection of a general right of contribution among joint tortfeasors. See Ennis v. Donovan, 222 Md. 536, 161 A.2d 698 (1960). At any rate, in Judge Thomsen's analysis there is no concern with the policy of the common-law rule denying contribution. Cf. William L. Prosser, Torts 246 (2d ed. I955).

${ }^{07}$ Klaxon Co. v. Stentor Elec. Mfg. Co., 313 U.S. 487 (I94r). Cavers and I are in agreement on the general soundness of the Klaxon rule, and there is no reason to discuss that matter here; but for future discussion we may reserve a question as to whether an exception should be made for the typical situation of the disinterested third state. See note 126 infra.

${ }^{88}$ Letter from Judge Thomsen, to the author, August $15,1963$. 
would not have avoided the problem of choice of law but would almost certainly have resolved it by virtually insuring the application of North Carolina law. ${ }^{50}$

Application of the law of the place of the tort (North Carolina) would entitle the defendant to contribution from the husband. ${ }^{.0}$ Uncritical application of the law of the domicile (Maine), in reliance on Emery v. Emery ${ }^{61}$ and Haumschild $v$. Continental Cas. Co., ${ }^{62}$ would deny contribution. ${ }^{63}$ Application of the internal law of the forum (Maryland) would also deny contribution. Faced with such a situation, what should the federal court in Maryland do?

While noting the recent decisions that have applied the law of the domicile, Judge Thomsen accepted as authoritative in Maryland the rule that the law of the place of the tort controls, unless it is contrary to the strong public policy of the forum. $^{64}$ In considering the public policy question, however, he inquired carefully into the purposes of the immunity rule in Maine and Maryland, his method being substantially identical with that called for by governmental-interest analysis. At first it is difficult to detect any policy element in the immunity rule. The decisions announcing it were based simply on the fact that no right of action by the wife against the husband existed at common law, and none had been created by statute. Later a policy foundation for the rule is made explicit: "...the broader sociological and political ground that [such a right of action] would introduce into the home, the basic unit of organized society, discord, suspicion, and distrust, and would be inconsistent with the common welfare." ${ }^{35}$ That policy extends to situations in which the wife seeks to recover indirectly by suing a third person who in turn may seek contribution or indemnity from the husband. ${ }^{66}$ Judge Thomsen contributed an additional policy consideration on his own initiative: "... the more realistic reason for refusing to permit tort actions by a wife against her husband-that they are likely to result in a collusive effort to mulct the husband's insurance carrier...."

${ }^{80}$ See note 52 supra. Doubts persist as to the effect of transfer on the law to be applied in the federal courts. See Currie, op. cit. supra note 3, ch. 9; Cavers, supra 732, at 747. But when the forum is not only inconvenient but disinterested it would be fantastic to expect its choice-of-law rules to be applied by the interested transferee forum-especially where, as here, those rules have not been announced. See text at note 145 infra.

${ }^{60}$ North Carolina not only allows the wife to sue the husband, but rigidly applies the law of the state of the tort on that issue regardless of the domicile. Bogen v. Bogen, 219 N.C. 5I, I2 S.E.2d 649 (x94I); Shaw v. Lee, 258 N.C. 609, I29 S.E.2d 288 (I963).

${ }_{01} 45$ Cal.2d 42r, 289 P.2d 218 (1955).

${ }_{7} 7$ Wis.2d r30, 95 N.W.2d 814 (1959).

- $T$ Those cases have inspired a new section of the Restatement referring questions of intra-family immunity to the law of the domicile. Restatement (Second), Conflict of Laws $\$ 390 \mathrm{~g}$ (T'ent. Draft No. 8, I963). But the section is limited to actions between members of the family, and does not apply to actions for contribution between joint tortfeasors because "In this situation the state of the family domicile does not have the same interest in determining the question of immunity as it does when the suit is between members of the family...." Id., comment $c$ at 149 . In the contribution cases the Restatement refers to the law of the state having the "most significant relationship" (id. $\$ 379$ ), which appears to be the state of the tort in disguise.

os 215 F. Supp. at 164 .

${ }^{a s} 215$ F. Supp. at 165 , quoting from Riegger v. Bruton Brewing Co., 178 Md. 518, 522, 16 A.2d 99, IOI (I940).

${ }^{88} 215$ F. Supp. at 165 .

${ }^{67} 215$ F. Supp. at 166. 
Analyzing the case before him in the light of these policies, Judge Thomsen decided that the motion to dismiss the third-party complaint should be denied.

The structure of the opinion is traditional, and it is possible to read the argument simply as a series of traditional propositions. To avoid any misinterpretation the argument should be stated in those terms: According to the Maryland choice-of-law rule, the law of the place of the tort governs, provided it is not contrary to the strong public policy of the forum; while Maryland would not in a domestic case require the husband to contribute, that is not because of reasons of strong public policy but because of the technical rule that there can be no contribution without direct liability of husband to wife; North Carolina law, made applicable by the choice-of-law rule, supplies the element of direct liability; and the result is not obnoxious to any strong public policy of Maryland. In my judgment, however, there is more in the opinion than this. If this were all there would have been no occasion for Judge Thomsen's concern with the policy of Maine, nor for his detailed attention to the facts. Without violence to the opinion the argument can be restated in terms of the analysis used in this paper: Maryland was in the position of the disinterested third state. Having no interest in the application of its own law and policy, it was confronted with an apparent conflict between the interests of Maine and North Carolina. But after careful analysis the interest of Maine could be moderately defined, with the result that conflict was avoided and the law of the only interested state was applied.

In these terms Judge Thomsen took the interest of North Carolina for granted; and in fact this is a situation in which the place-of-the-tort rule is consistent with North Carolina's interests. That state's imposition of liability on the husband for injuries to the wife may well express two policies (apart from the obvious one of compensation for the victim): (a) deterrence of negligent conduct and (b) especially in the light of liability insurance, provision of a fund from which medical creditors can be reimbursed. As the state of both conduct and injury, North Carolina could reasonably assert an interest in applying both of these policies.

As to the interest-or at least the policy-of Maine Judge Thomsen was explicit, although there was no occasion to be concerned with Maine if the purely traditional argument was sufficient: ${ }^{68}$

It is probable that the Maryland Court, sensitive to all questions of comity, would not only consider whether the enforcement of the third-party claim in this case would violate any strong public policy of the State of Maryland, the forum, but also whether the enforcement of that claim would violate any strong policy of Maine, the domicile of the husband and wife.

At first sight Maine appears to have a clear interest in the application of its maritalharmony policy where its own domiciliaries are concerned. Equally it appears to have an interest in the application of its policy of protecting liability insurers where the insured is a resident of the state and the underwriter is presumably licensed to

${ }^{\text {os }} 215$ F. Supp. at I65 (footnote by the court omitted). 
do business there. ${ }^{69}$ But the husband himself was simultaneously suing the defendant for the injuries suffered by him. He and his wife had a common interest in fixing liability on the defendant rather than on the husband, since if he was liable to contribute as a joint tortfeasor he must have been guilty of contributory negligence. It was the defendant, not the wife, who asserted the claim against the husband. In these circumstances there was no prospect of family discord and no threat of collusion to the detriment of the husband's insurance carrier. Hence one may reasonably conclude that Maine has no interest in the application of its policy, or at least that Maine would in the circumstances refrain from asserting an interest. ${ }^{70}$

With respect to the interest, or lack of interest, of Maryland the opinion is less specific, though the neutrality of the forum is suggested: "This is an unusual case, in that the forum is neither the place where the accident occurred nor the place where the husband and wife are domiciled."71 Since the choice-of-law rules being considered pointed only to the place of the tort and to the domicile, it was assumed that the law (as distinguished from the public policy) of the forum was irrelevant. We may be thankful that no advantage was taken of the opportunity to apply the law of the forum because the rule of immunity was "procedural," stemming from the common-law incapacity of the wife to sue in her own name. ${ }^{72}$ Certainly there is involved no policy of Maryland relating to the convenience of trial or to the integrity of its processes of judicial administration. Maryland's policy of preserving marital harmony is not directly relevant because the husband and wife are domiciled elsewhere; and even if Maryland were disposed to extend its anti-collusion policy for the protection of the husband's Maine underwriter, it would clearly not do so, in Judge Thomsen's view, where there is in fact no threat of collusion. Hence we may conclude that Maryland was in fact a disinterested forum.

\section{The Unavoidable Problem}

So much for avoidance of the problem, whether by declining to exercise jurisdiction or by construing away the conflict. Eventually we must deal with the conflict that cannot be avoided. It is not easy to vary the facts of the LaChance case to generate such a conflict, and the reasons may indicate why the case of the disinterested third state is rare. Suppose that Mrs. LaChance had sued Mr. LaChance himself in Maryland for her injuries. That would present the Maryland court with a conflict between North Carolina and Maine; but if we are at all realistic we must recognize that such an alteration in the facts will tend either to make the Maryland court an

${ }^{\circ 0}$ Fraudulent claims against residents of Maine might have a tendency to raise insurance rates in that state because such rates are based on the loss experience of insured persons residing in the rate area. But see Morris, Enterprise Liability and the Actwarial Process-The Insignificance of Foresight, 70 YaLE L.J. 554 (I96r).

${ }^{70}$ An apparent flaw in this reasoning is that the argument demolishes also Maine's policy basis for disallowing contribution in a domestic case of exactly the same type. But it does not follow that, if this precise case had arisen in the courts of Maine, those courts would not have reached the same decision as that reached by Judge Thomsen; to avoid conflict with the interest of North Carolina, they might have defined domestic interests in the fashion of the Bernkrant case.

71215 F. Supp. at 165.

${ }^{72}$ Cf. Mertz v. Mertz, 27I N.Y. 466, 3 N.E.2d 597 (1936). 
inappropriate forum or to provide a possible basis for Maryland's asserting an interest in applying its own law.

In my own researches I have encountered an actual case of the disinterested third state only once, I believe; and even in this instance the conditions of the problem are not clearly met. The case is Dimon $v$. Dimon. ${ }^{73}$ The wife, domiciled in Connecticut, there obtained an ex parte decree of divorce, the husband being then domiciled in Nevada. ${ }^{74}$ For added interest, assume a fact not in evidence: that the husband similarly obtained an ex parte divorce in Nevada. Later she sued him in California for alimony. Since both were nonresidents one might suppose that dismissal on forum non conveniens grounds would be considered, but California had not yet adopted that doctrine. ${ }^{75}$ According to the law of Connecticut the wife's right of support survived a valid decree of divorce in which the right could not be adjudicated; according to the law of Nevada, the right did not survive a valid divorce. $^{78}$ The majority opinion did not treat the case as one of choice of law at all, but simply held that under the law of California the right did not survive. Justice Traynor, in dissent, treated the problem as one of choice of law; assumed that the law of Connecticut was relevant without noticing the possible conflict with Nevada; in the absence of adequate information as to the law of Connecticut, presumed it to be the same as the law of the forum; and argued that under California law the right survived.

Treating the case as presenting the problem of the disinterested third state, I concluded that in such a situation the forum may reasonably apply its own law, whatever it may be. (It soon became the law of California that the right to support survives.) ${ }^{77}$ Vulnerable though it may be, I do not propose here to re-examine that conclusion in the context of the Dimon case. Because of confusing overtones of constitutional doctrines relating to recognition of divorce decrees the case is a difficult one to discuss in terms of pure choice of law. I shall only suggest to those who are interested in formulating their own conclusions that the problem is not resolved, as might be supposed at first blush, by the proposition that an ex parte decree of divorce cannot cut off the personal right to support. ${ }^{78}$ That proposition has no application unless there is a right to support that survives a valid divorce, ${ }^{70}$

${ }^{73} 40$ Cal.2d 516, 254 P.2d 528 (r953), noted 37 Mare. L. Rev, 279 (1953-54), 26 So. Cal. L. Rev. 325 (1953). I have discussed the case in Currie, Justice Traynor and the Conflict of Laws, I3 STAN. L. REv. 719, 754-57 (r961); CurRie, op. cit. stipra note 3 , at 664-67.

"We know that he was domiciled in Nevada at the time of the subsequent action in California; that he was domiciled there at the time of the divorce is an assumption made to fit the case more neatly into the mold of the disinterested third state.

${ }^{70}$ It adopted the doctrine the following year in Price v. Atchison, T. \& S.F. Ry, 42 Cal.2d 577, 268 P.2d 457 (1954).

${ }^{70}$ The first of these statements in particular involves a considerable degree of assumption, made for the purpose indicated in note 74 supre. The Connecticut decisions were inconclusive. The statement as to the posture of Connecticut law is justified only by artificial reasoning based on the dissent of Justice Traynor, discussed in the text immediately following.

${ }_{77}$ Hudson v. Hudson, 52 Cal.2d 735, 344 P.2d 295 (1959).

${ }^{78}$ Estin v. Estin, 334 U.S. 54I (1948). (1956).

Esenwein v. Esenwein, 325 U.S. 279, 280 (I944). Cf. Vanderbilt v. Vanderbilt, 354 U.S. 4 I6 
and in this case the problem is to determine whether there is such a right under the appropriate law.

Only Michael Traynor, so far as I know, has discussed this problem in the context of an actual case with confidence that the case presents the problem in its pure theoretical form. ${ }^{80}$ The case is Forgan v. Bainbridge, ${ }^{81}$ presenting a familiar problem in the rare context of three states rather than two. Tallmadge bought an automobile in Illinois, giving a chattel mortgage that was assigned to Forgan and duly recorded. He then took the car to Texas and pledged it to Bibb as security for his performance of the condition of a bail bond. He defaulted, and Bibb sold the car in Texas to Bainbridge, a resident of Arizona. Forgan sued to replevy the car in Arizona. Under the laws of Illinois and Arizona the mortgagee prevails over the bona fide purchaser. Under the laws of Texas the bona fide purchaser prevails. A divided court ordered judgment for the plaintiff in accordance with the laws of Illinois and Arizona, reasoning that the rule favoring the mortgagee is the better rule, followed by the great majority of the states; that the law of Illinois was the same as the law of the forum; and that on the principle of reciprocity (more accurately, it would seem, of retaliation) Arizona should refuse to recognize a title acquired in Texas by a bona fide purchaser when Texas would refuse to recognize a title acquired in Arizona by a mortgagee.

The case does appear to present the situation of a neutral forum confronted with a conflict of interests between two other states, or as close an approximation of that phenomenon as we can achieve on the interstate, as distinguished from the international, plane. ${ }^{82}$ Nevertheless, it is not an attractive case on which to focus the present discussion. Despite the general agreement that the rule favoring the mortgagee is preferable, the fundamental problem of choice of law is a thorny one that I should like to analyze carefully in terms of governmental interests in the normal two-state situation before venturing to comment on it in the rare situation of the neutral forum. Because of the general agreement that the rule favoring the mortgagee is preferable, the political element in the choice made by the court is somewhat obscured. Therefore I simply note here Michael Traynor's views on the case: The neutral forum must and should weigh the competing governmental interests; application of the law of the forum by default is irresponsible abdication;

${ }^{80}$ M. Traynor, Conflict of Laws, 49 Calrf. L. Rev. 845, 862-67 (I96I).

8134 Ariz. 408, 274 Pac. I55 (I928). This is a "casebook" case. See Elllott E. Cheatham, Herbert F. Goodrich, Erwin N. Griswold \& Willis L. M. Reese, Cases and Materials on Conflict OF LAws 677 (4th ed. 1957).

${ }^{89}$ A decent argument might be made that although Arizona's primary interest is in protecting local mortgagees, that interest is expanded by force of the anti-discrimination clauses of the Constitution to include protection of citizens of other states, and of all persons within her jurisdiction. Sce Cunnie, op. cit. supra note 3 , chs. IO, II. This would mean not only that Arizona must protect the nonresident mortgagee but also that another disinterested forum, with a law like that of Texas, must protect the nonresident bona fide purchaser. A state may almost certainly classify persons according to the laws of their home states, but here it is assumed that the mortgagee's (or the bona fide purchaser's) home state would give him the same protection as the law of the forum. On the other hand, a purpose to avoid conflict with the interest of another state also is a reasonable basis for classification; and though one state's interest must necessarily suffer in this situation, I am not prepared to argue that the Constitution requires that this be the state that disagrees with the forum. 
there are several ways of resolving the conflict, each preferable to application of the law of the forum by default; even the principle of reciprocity (retaliation), offensive to Traynor, is preferable; ${ }^{83}$ the Illinois rule is the better rule, and applying it will promote interstate harmony because it is followed by the majority of the states. Other solutions are canvassed, including the imaginative and semi-serious one of dividing the loss equally between the mortgagee and the purchaser; each is preferred to application of the law of the forum "by default," because each is at least rational, while the default solution is the product of despair.

So much for the cases on which the present discussion is not to be focussed. ${ }^{84}$ For purposes of the discussion we need (a) a case conforming with reasonable plausibility to the hypothetical model, (b) an issue with respect to which policies and interests are clear, and (c) an issue concerning which there can be a reasonable amount of disagreement among men of good will. I therefore turn with some misgivings to hypothetical cases based on actual two-state cases, beginning with Kilberg v. Northeast Airlines. ${ }^{85}$ Assume that an otherwise identical action is filed in State $F$; that service of process on the defendant is sustained because it is licensed to do, and is doing, business there; that for sufficient reasons the action is not dismissed on forum non conveniens grounds; and that the court disclaims any interest in applying the law of the forum on the issue of damages (as it should do since the

${ }^{83}$ I shall not discuss this ground of the decision further. There is little point in disputing whether it is preferable to application of the law of the forum simply as such, since the result is the same, and since we are in agreement that the retaliation-reciprocity concept is unseemly. I believe that concept should have no place in American interstate conflict of laws, reserving the right to argue that it may have a place in international conflicts. Cf. Hilton v. Guyot, 159 U.S. I13 (1895).

${ }^{84}$ One more actual case deserves sufficient mention to record it for future reference. Hans Baade has called to my attention a decision of the (West) German Supreme Court, commented on in GrRHArd Kegel, Die Grenze von Qualifiration und Renvol im internationalen Verjährungsrecht (1960). An Illinois manufacturer sold chocolate to a buyer in Louisiana. He sued in Germany, where the buyer had assets, to recover the unpaid balance of the price. The period of limitation prescribed by Illinois had not expired; that prescribed by Louisiana had. The German court held that the law governing limitations is that governing the obligation, and referred to the law of Louisiana as the place of performance; but that reference included the conflict-of-laws rules of Louisiana, so the case was remanded for a determination of whether Louisiana might refer to the law of Illinois. Professor Kegel's view was that, since both Illinois and Louisiana refer questions of limitation to the law of the forum, German law was applicable by virtue of a rather fanciful kind of renvoi: "Although, actually, American courts would not apply German law, they would do it, hypothetically, if confronted with the problem." (Id. at 45. The quotation is from 2 summary in English of Kegel's German text.) That is to say, if I understand the argument, that although American courts do not decide cases in German courts, if they were somehow to find themselves in the position of doing so they would apply German law as the law of the forum.

The case may present the problem of the disinterested forum. Rather clearly Germany disclaims an interest in protecting the administration of justice in her courts against stale claims. Possibly the Illinois statute can be construed as giving the seller a minimum time in which to press his claim, and the Louisiana statute as protecting the buyer against stale claims. If so, a conflict between Illinois and Louisiana could be found. If, however, those states simply repeat the formula that the question of limitations is a matter of procedure, governed by the law of the forum, it will be difficult to attribute to either state a party-favoring policy, with the consequence that the case will not present a conflict of interests between them. Since none of the three states has any interest in barring the action, it should proceed to judgment.

Given a more leisurely opportunity to circumvent the language barrier, I hope to consider the case more fully in the future.

${ }_{95}^{9}$ N.Y.2d 34, I72 N.E.2d 526, 2 II N.Y.S.2d 133 (I96I). 
accident did not arise out of business transacted in State $F$ by the foreign corporation). Assume further, for the time being, that the law of State $F$ on damages is the same as either that of New York or that of Massachusetts. The problem is: What are the reasonable ways in which the court can decide the case?

For present purposes I assume that the case must be decided in accordance with the law of one of the three states. There can be no resort to a super-law such as the erstwhile general federal common law. There will be no compromise, such as splitting the difference, if that is conceivable in this case. There will be no talk of retaliation and reciprocity. There will be no coin-flipping. The choice will not be made in terms of alphabetical order ${ }^{86}$ nor of the dates on which the respective statutes were enacted. Evidently the interest of one state or the other must be sacrificed. Which shall it be, and why?

The point has already been adequately made, I believe, that the old rule that the law of the place of the tort controls has little to commend it. It does have the meager virtue of relative simplicity; a nasty problem has to be solved, and this rule permits its solution without the travail of thought. It also allows one to predict the outcome of the action after the accident has happened-provided the action is brought in a disinterested third state. But these virtues are possessed also by the rule of alphabetical order, and that rule has the additional advantage that it has no supernatural overtones suggesting that the designated state has exclusive "legislative jurisdiction." Such overtones enhance the danger that the chosen rule will ultimately come to be applied in the normal two-state situation, with clearly indefensible results.

Consider next the injunction of the Restatement Second, bearing in mind Reese's statement that this is exactly the kind of situation for which the Restatement is designed. True, we do not yet have before us the new prescription for damages in wrongful death cases; ${ }^{87}$ we do have, however, the new rules on personal injuries and on tort damages generally. ${ }^{88}$ These refer the question of damages for personal injuries to "the state which has the most significant relationship with the occurrence and with the parties." This is "almost invariably" the state in which wrongful conduct and injury concur. ${ }^{90}$ The old rule's disguise is thin. But if Kilberg is one of the very rare cases in which another state can be the state of most significant relationship, how is that conclusion to be reached?

Other factors can be considered, including the domiciles of the parties. ${ }^{01}$ The Columbia Law Review, which presumably has access to the advice of Professor Reese, has thus assessed the factors in the Kilberg case itself: ${ }^{92}$

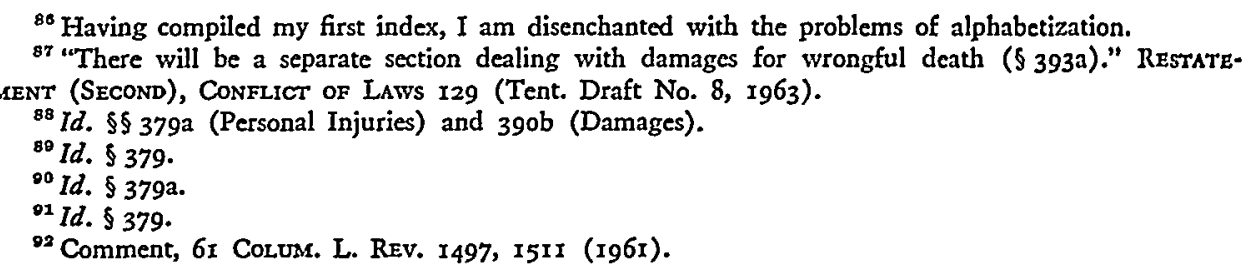


It seems clear that the significant territorial interests in the case were those of Massachusetts, and in view of the defendant's domicile in Massachusetts, the decedent's domicile in New York did not create a dominant countervailing interest in the latter state. Therefore, it is doubtful that this was a proper case for departure from the place of wrong rule.

That comment was directed to the case in the New York courts. Will all those who favor the same analysis for the case in State $F$ please rise?

What will the new rule on damages in wrongful death cases provide? A reporter is not the alter ego of his client, but perhaps we can find a clue of sorts in the reporter's contribution to this symposium. Referring to his policy (No. Io) to the effect that the court should seek to attain justice in the individual case, Reese says: ${ }^{93}$

It is believed that this policy is most likely to carry the day in situations in which normal choice-of-law rules would lead to the application of the law of a state which adopts a minority view that is out of tune with the times. Here it is only to be expected that the court will search for a choice-of-law rule that would lead to the application of the law of some other state. Kilberg v. Northeast Airlines, Inc., is a case in point.

Very well. If that is what the New York court did in Kilberg (I do not think it is), perhaps the court in State $F$ will do the same-provided the law of State $F$ is the same as that of New York. But what if the law of State $F$ is the same as that of Massachusetts? Conceivably the court in State $F$ might say:

We have long regarded the policy of arbitrarily limiting recovery in wrongful death cases as one that leads to injustice in the individual case. It is a minority view, out of tune with the times. We are sworn to apply that policy in domestic cases, and we do so because we have no alternative. Still faithful to our duty, we apply that archaic policy even when it comes in conflict with the more enlightened policy of progressive states such as New York. But in this case no interest of our own is at stake, and we are free to apply what we conceive to be the better and more useful law. Perhaps this will teach our legislators a lesson.

The court might say this. Is there not some possibility, however, that it might reason differently, impelled by some tendency to apply the foreign law that agrees with its own?

If courts are to be free to proceed in this manner, it seems clear that the most publicized objectives of the system of conflict of laws-uniformity of result regardless of forum; simplicity, certainty, predictability-must go by the board. No matter. I believe that far too much emphasis has been placed on those objectives, and their significance is materially reduced in the narrow context of the problem of the disinterested third state. Let us come directly to the heart of the matter: Is this the way in which we want courts to decide cases?

Many people are distressed by strong language to the effect that resolution of the conflicting interests of co-ordinate states is a high political function that courts are not equipped to perform, and that therefore the problem should be regarded as insoluble with the resources of the law of conflict of laws. Let us try to avoid such

${ }^{09}$ Reese, supra 679, at 690 . 
language. If the problem is susceptible of solution by human intelligence, as it obviously is, then it can be solved by judges; for judges are men like legislators and diplomats, and no less intelligent. To some extent they are trained in the same way as legislators, and even selected for office in similar ways. To some extent they have similar ways of obtaining needed information. The question is, do we want to commit the resolution of such conflicts to judges on this basis? Quite possibly, for the case of the disinterested third state, the answer may be yes. If the phenomenon is as rare as I think it is, the problem is not nearly serious enough to warrant its solution in the manner contemplated by the Constitution: by act of Congress pursuant to the full faith and credit clause. Subject to just three reservations, I can contemplate with at least equanimity an opinion from the supreme court of State $F$ along these lines:

We are confronted with a rare and difficult problem, but the case must be decided. The problem might have been solved by act of Congress, but it has not been sufficiently recurrent to warrant the attention of that body. There are no established principles of law to guide us. Our task is simply to place ourselves in the position of Congress, and to reach the decision we think Congress would reach if it were to consider the matter. In assuming this role we put aside the fact that we are a court of State $F$. The posture of our law on the subject is no more material than that of any other statc. Our viewpoint has become that of a guardian of the national interest. Having considered the matter in this light, we are persuaded that the rule allowing full indemnity is the more enlightened and humane one, and accords best with the needs of our society; that the arbitrary limitation on recovery is unjust and outmoded; and that when the interests of two states in the application of these policies come into conflict, the interest in protecting the defendant against what is regarded as oppressive liability should yield to the interest in awarding full indemnity.

\section{Or would the decision go the other way? ${ }^{94}$}

The first reservation: The decision must be in just such terms. The court is exercising a function committed to Congress because Congress has not acted, and because the case must be decided. Let there be no talk of the legislative jurisdiction of the respective states. Let there be no mechanical rules for choice of law. Let there be no talk of the state having the "most substantial relationship with the occurrence and with the parties." Let there be no talk of the "center of gravity," the "grouping of contacts," the "proper law." Let there be no talk of "weighing" the respective interests, no singling out of one interest as "dominant" or "paramount." Of course our ancestral pretense that courts do not make law means that this is a hard injunction to lay upon a court. But would it not make for clarification of our problems if law professors, at least, would agree to such a condition of discourse?

'Let me venture a guess: In many courts it would go the way of the hypothetical opinion in the text. If the matter were acted upon by Congress, however, there would be heavy pressure from the airlines, the railroads, and others interested in minimizing liability (dead men have no lobbyists), with the probable result that liability would be limited-more likely by action under the commerce clause than under the full faith and credit clause, thus, incidentally, taking the whole matter out of the hands of the states. Does this estimate of the probabilities have anything to do with the attitudes of law professors toward the problem? 
The second reservation: The technique must be strictly confined to the case of the disinterested third state. This mode of decision is a heady wine. There is danger that, having tasted such power, the judges will be tempted to exercise it when it would sacrifice the interest of the forum state. But judges who disapprove domestic statutes must confine themselves to the technique of construction. Let them construe narrowly if they will, but let them construe-and say that that is what they are doing.

The third reservation: There may be some validity, after all, in the suggestion I have previously made, that in such a situation as this the court might reasonably apply the law of the forum. It is not altogether fair to say that this would be done "by default," or that it is "abdication," or that it is "defeatist." Some courts may wish an alternative to frankly assuming the role of supreme legislator. I can imagine an opinion from State $F$ along these lines:

In modern times we have learned that law is an instrument of social control; that laws are made for the implementation of social policy; and that in deciding questions of the conflict of laws prime attention must be given to the governmental policies expressed in laws. Of all this we are persuaded, but it does not lead us to a decision in this case. Whichever way we decide, the policy of one foreign state or the other will be defeated, while our own will be unaffected. We have our personal views as to which of the competing policies is preferable, but we hesitate to impose those views on the disfavored state and on these parties in the name of law. Is not our law, after all, more than an instrument of social control? It is also a body of rules for the just adjudication of controversies between private parties. Our legislature and our courts have considered whether, as a matter of justice as well as social policy, damages for wrongful death shall be limited. The plaintiff has resorted to our courts seeking justice; the defendant has not resorted to our courts, to be sure, but it has by doing business here subjected itself to our jurisdiction in many cases in which we cannot conscientiously refuse to exercise it. Since we cannot meaningfully decide the case in terms of governmental interests, should not justice between the parties be the prime consideration? And where shall we look for justice but to the rules devised by our legislature and our courts for our own people? ${ }^{95}$

How shall we choose between this approach and that of unfettered choice between the conflicting interests? If the law of the forum is to be applied we may assume that the plaintiff would hardly resort to the unusual forum unless its law were in correspondence with New York's; so that this approach may encourage forum-shopping, while free choice would at first leave plaintiffs in doubt. But may we not say that the problem of forum-shopping was dealt with, and adequately, when the assumed motion for dismissal on grounds of forum non conveniens was denied? The constitutionality of this approach has been doubted. ${ }^{96}$ I respect the doubters but do not share their doubts. "Prima facie a state is entitled to enforce in its own courts its own statutes, lawfully enacted."197 In this case no one has shown and no

${ }^{05}$ Cf. Currie, op. cit. supre note 3 , at $64-65$.

${ }^{\circ 8}$ See Schreter, "Qutasi-Commutnity Property" in the Confict of Laws, 50 CalIF. L. Rev. 206, 233 n.172 (1962); cf. Hill, Governmental. Interest and the Conflict of Laws, 27 U. CHr. L. REv. 463, 478 (1960).

${ }^{97}$ Alaska Packers Ass'n v. Industrial Acc. Comm'n, 294 U.S. 532, 547-48 (1935). 
one can show in terms of governmental interests that the law of the forum ought to be displaced by a particular foreign law. Moreover, let us return for a moment to Michael Traynor and Forgan v. Bainbridge: if the disinterested forum may constitutionally apply the law that coincides with its own, because it is the better law and the majority rule, and its application promotes interstate harmony, how can it be unconstitutional for State $F$, even if its law coincides with that of Massachusetts, to apply that law on the ground that though it may be in the minority it is still the better rule? It may be well to remember that not all minority rules are archaisms. Almost all progressive innovations in the law are in the minority for a while.

I do not feel impelled to commit myself irrevocably to either approach at this time. If I were a judge I think I should prefer application of the law of the forum to the bolder technique. But then, I am a pretty old-fashioned fellow.

An important qualification must be stated. Here we have carefully stipulated that the forum's law coincides with that of one of the other states. That is the situation I have visualized in suggesting that the law of the forum may be appropriate. If that condition is not met the problem may be radically altered, and application of the law of the forum may be unwarranted and unconstitutional. Suppose that the disinterested forum allows unlimited recovery; the law of the domicile of the decedent limits recovery to $\$ 30,000$; and the law of the corporate domicile and of the tort limits recovery to $\$ 55,000$. Application of the forum's law is clearly unwarranted. The maximum recovery should apparently be $\$ 30,000$. Perhaps the best approach to solution of such a problem is to conclude that there is no basic conflict of policy between the foreign states: both are committed to a policy of limitation, having settled upon different limits within a tolerable range; their laws differ not as black and white but as shades of gray; award of the greater sum will advance the common policy of compensation, or deterrence, without grave impairment of the policy of the other state. ${ }^{98}$ But conceivably there may be three wholly different rules of law for the solution of a social problem: the law of State $F$ may be red, that of State $X$ white, and that of State $Y$ blue. Having no idea what kind of problem and what kind of rules would be involved in such a situation, I shall not attempt to say how the choice should be made. I only record the fact that I am not sure that application of the law of the forum would be justified in such a case, and that there may be no alternative to the free choice that amounts to the exercise of pure legislative judgment.

In the employment of choice-of-law rules rather than governmental-interest analysis it may be that we resolve conflicts between foreign states with some frequency without being aware of it. A brief exploration of this possibility may throw further light on the prospects for devising choice-of-law rules for the solution of such conflicts.

Imagine a scene in a probate court of State $F$ :

\footnotetext{
${ }^{\circ 8}$ Cf. Kinney Loan \& Finance Co. v. Sumner, 159 Neb. 57, 65 N.W.2d 240 (1954), discussed in CuRrae, op. cit. supre note 3, at 186.
} 
Counsel: If your Honor please, as counsel for the administrator with the will annexed I ask leave to file a petition for instructions in the matter of the estate of Mrs. Julia Hungerford, deceased.

Court: What is the problem? The will seems in order. There are no debts. Why should you not distribute the assets to the named beneficiaries?

Counsel: This is only an ancillary administration, your Honor. Mrs. Hungerford died domiciled in State $X$. The assets here consist entirely of savings accounts in a building and loan association. An executor holding letters testamentary issued by an appropriate court of State $X$ has filed a claim asking that the funds be delivered to him for distribution in accordance with the law of that state.

Court: What is the point?

Counsel: The will leaves the surviving husband only $\$ 5,000$. Under our law there is nothing he can do about that. But under the law of State $X$ the husband may renounce the will, as he has elected to do, and claim one-half of all the wife's personal estate..$^{99}$

Court: Very well. It is established that the law of the domicile governs the validity and effect of a will of movables. You propose to turn over the funds to the executor?

Counsel: There is this complication, your Honor. Although she was domiciled in State $X$, Mrs. Hungerford was a national of State $Y$, an obscure country somewhere in Europe. A claim has been filed by one claiming to be her "universal successor" under the law of State $Y$, according to which...

Court: Never mind the law of State $Y$. You are not suggesting that the law of State $X$ refers us to the law of the nationality? ${ }^{100}$

Counsel: No, your Honor.

Court: Then that is the end of the matter. The funds will be remitted to the executor for distribution in accordance with the law of the domicile.

Neat enough, perhaps. Of course, if the law of State $Y$ differs from that of State $X$, and $Y$ asserts an interest in the application of its law, the interest of $Y$ will be defeated; but that one interest must suffer is inevitable in this situation. Certainly our methods might be worse. In his little book of lectures entitled Polarized Law, Thomas Baty discusses the principle of domicile in terms that are largely pragmatic; without too much strain he can be understood to argue that England should adopt a moderate and restrained definition of her interest in applying her policies relating to succession upon death. She should not take advantage of her control of movable property to impose her policy on foreigners; nor should she lay hold of the fact of English nationality to impose her policy upon Englishmen domiciled abroad. Conversely, England defers to the interest of the foreign domicile, but not to the asserted interest of the state of nationality when the decedent was domiciled in England. But at this point something goes awry. Suddenly a pragmatic definition of gov-

${ }^{\circ \theta}$ Because I always feel insecure in discussing problems of conflict of laws without a realistic and specific issue, the difference in law employed here is taken from Riley v. New York Trust Co., $3{ }^{2} 5$ U.S. 343 (1942); see s.c. below sub nom. New York Trust Co. v. Riley, 24 Del. Ch. 354, 359-60, I6 A.2d 772, 775 (Sup. Ct. 1940). There is a certain appropriateness in the choice, since there the Delaware court was a disinterested forum; but of course, since there was complete agreement that the law of the domicile was controlling, the case is not directly relevant.

${ }^{100}$ Cf. Restatement (Second), Conflict of Laws $\$ 306$ (Tent. Draft No. 5, 1959). 
ernmental interests becomes a Rule. Twice over Baty states a remarkable proposition: ${ }^{101}$

Further, I take it that that principle of English law, arrived at on considerations of common sense, and natural propriety and convenience, is for the English courts a universal rule. That is, the English court would not only say that it is to be applied when foreigners settle in England, or when a British subject settles abroad, but also when the subject of one foreign country settles in another. Should a Swede settle in Portugal, then I take it that without considering what Swedish law says on the subject, the English law, should a question involving the personal status in private law of the Swede come before it, would treat it as regulated by the law of Portugal, the place of his domicile.

If it is right to apply English law to a Dutchman because he lives in York, and right to apply Dutch law to an Englishman because he lives in Rotterdam, it must be equally right to apply French law to an Italian because he lives in Paris.

At least from the standpoint of governmental-interest analysis, this is pure pigheadedness. There may be no conflict at all between the foreign states: Sweden and Portugal (or France and Italy) may concur in asserting an interest in the application of their respective policies only when the deceased is a national. If the objective is unitary administration of a single estate, and if we assume assets in all three countries, England, while disclaiming an interest, irrationally disrupts an administration that is uniform in the other two states. This is enough to persuade me that there is validity in the principle of renvoi in the context of the disinterested forum. We may be grateful that the Restatement Second provides protection against this absurdity ${ }^{102}$

But to return to Mrs. Hungerford's estate: Is the way of the Restatement Second the most reasonable way to go about resolving the conflict between the two foreign states? ${ }^{103}$ Is it preferable to applying the law of the forum where that coincides with one of the foreign laws? Is it preferable to free choice between the competing policies and interests? A possible hypothesis is that there may be values (in the situation of the disinterested third state) simply in the preference of one rule for choice of law over another. The question concerns the validity of that hypothesis.

Perhaps the inquiry will be facilitated if we go back a step and translate the probate judge's thinking into the language of governmental-interest analysis:

101 T. Baty, Polarized Law 23, 26 (1914).

${ }^{102}$ Restatement (Second), Conflict of Laws $\$ 306$, comment $e$ (Tent. Draft No. 5, 1959). If we ask whether this one-way renvoi is sufficient protection the answer secms to be yes, at least in the simple case supposed. The question would be: Why not also look to the law of the nationality, which may similarly obviate conflict by reference to the law of the domicile? But the answer is that the same result is achieved by direct reference to the law of the domicile.

One may at least hope that the new section gives adequate protection. But what is the purpose of the reservation in the statement that the reference to the law of the domicile is to the whole law? "With respect to both tangible and intangible movables, the reference, subject to the considerations stated in $\S 8$, is to the law of the state where the decedent dies domiciled, including its Conflict of Laws Rules." Restatement (Second), Conflict of Laws $\$ 306$, comment $e$ (Tent. Draft No. 5, 1959) (emphasis added).

${ }^{103}$ Rather clearly this is not a case to be dismissed on anything like forum non conveniens grounds. The chances are that the building and loan association does no business outside State $F$, so that only 
This state has disclaimed any interest in applying its policy concerning a wife's disinheritance of her husband merely because we have control of movable assets of the estate. [If $F$ is a nation-state rather than a state of the Union it has also disclaimed such an interest merely because the decedent was a citizen or national.] We claim an interest in the application of our policy only when the deceased died domiciled here. Accordingly we recognize, so far as we are concerned, the interest of the state of foreign domicile. But here we are confronted with an assertion of interest by the state of nationality. We would not recognize that interest if it were asserted in opposition to our own. How shall we treat it when it is asserted in opposition to that of the foreign domicile? I can hardly treat it as unreasonable; State $Y$ has simply defined the scope of its interests differently. How, then, shall I resolve the conflict?

The problem now is to frame the argument to be made by counsel for the executor in support of choosing the law of the domicile. With the best will in the world, I find that argument difficult to formulate. Let me try:

If your Honor please, I shall not suggest that the court apply the law of State $X$ merely because that state agrees with us in treating the law of the domicile as controlling; I shall certainly not be so crude as to suggest that all states so defining their interests should stick together. I may remind the court, however, that all states of the United States, as well as many foreign countries, follow the principle of domicile; that this is the older principle, the principle of nationality being a product of relatively recent trends of thought that may perhaps be characterized as chauvinistic. In our internal policy we have weighed all the considerations and found in favor of the domiciliary principle. Might not the world, perhaps, be a somewhat better place in which to live if we were to lend the weight of our support consistently to this principle, and withhold our encouragement from those who dissent? Rather clearly this would be a better world if all states and nations were to agree on one principle in defining their interests. If we may not realistically aspire to such an ideal, may we not at least, by consistent adherence to the principle we have adopted, nevertheless move in that direction, setting an example for others and incidentally promoting simplicity, uniformity, certainty, and predictability ${ }^{\text {104 }}$

I am not much impressed with this effort. The clearest objective is uniform administration of the assets of a single estate, but application of the law of the domicile will achieve that result no better and no worse than application of the law of the nationality or of the forum. It is difficult to believe that by following the suggested course we can persuade even a single state to abandon its adherence to the nationality principle. Even if we could, that objective has a strongly political tinge. If such uniformity in rules for choice of law is indeed desirable, the direct way to its attainment is through a treaty ${ }^{105}$ or other political action. In making that

that state has control of the fund. A possibility is that persons amenable to process in States $X$ and $Y$ owe money to the building and loan association, so that the executor and the universal successor might proceed by way of garnishment. The probable result if the laws of those states differ would be double liability for the innocent association. This consideration suggests from an interesting angle that in the interpleader situation, at least, the difficulties of adjudication by the disinterested forum are clearly outweighed by the exigency of the need to decide.

${ }_{106}$ "Clearly it is impossible to make all laws alike. But it is a more hopeful proposition to make the rules for the choice of law alike-to have one and the same Private International Law everywhere." BATY, op. cit. supra note Ior, at Io.

${ }^{100} \mathrm{Cf}$. the Hague Private Law Conventions printed as an appendix to BaTy, op. cit supra note zor. 
political objective a criterion of adjudication do we not make the parties pawns in a game of pressure politics, in much the same way as when we deal in retaliation and reciprocity? ${ }^{106}$ In terms of certainty and predictability adherence to the law of the domicile is no whit better than application of the law of the nationality, so long as we follow the rule announced; and for simplicity nothing can beat a rule that the law of the forum applies. Besides, we can never be wholly consistent in our adherence to the law of the domicile; we have already decided that to avoid absurdity we must accept the domicile's reference to the law of the nationality.

In this narrow context, as generally in choice of law, the basic fault lies in the belief that we can accomplish useful purposes by the elaboration of logical arguments based on rules for choice of law without reference to the content of the internal laws of the states concerned. The argument for the executor must, to be plausible at all, resemble somewhat Michael Traynor's argument in favor of Arizona's application of the law of Illinois in Forgan v. Bainbridge: the law favoring the mortgagee is the better law, the majority rule; let us lend our support to it consistently and thus promote, if not interstate harmony, at least the quality of justice as administered in our courts. But the argument for the executor is a far cry from this. It speaks only in terms of choice-of-law rules, which are still empty and lifeless things, and says nothing of what will be the consequences for the parties if we accept the argument and go haring off after our political objective. If we are not alert the argument will cause us to forget what it is we are talking about. This, I suspect, is the history of the law of conflict of laws. We begin with a practical problem and imperceptibly get lost in disputations about the principles of domicile and nationality as universal rules for choice of law. We forget that what we are deciding is whether a particular wife shall be conceded testamentary freedom or whether her husband shall be conceded an indefeasible right to half of her movable estate.

If the choice is between the course urged by the executor and that urged by Michael Traynor and other advocates of free choice between competing interests, I vastly prefer free choice. But there remains as an alternative the law of the forum. Again, I do not feel impelled to commit myself as to that at this time. There may be other alternatives to be considered. The problem needs much more analysis in terms of governmental interests, in the light of other concrete issues.

A final word, just to indicate one of the directions that may be taken by future analysis, now that renvoi has come into the picture. Shaw v. Lee $e^{107}$ presents the case of a North Carolina wife injured in Virginia by the negligence of her husband, Virginia having retained and North Carolina having abolished interspousal immunity. North Carolina has woodenly adhered to the law of the place of the tort. Suppose that after the next similar accident the wife sues in Virginia, and that counsel is able to persuade the court that Virginia has no interest in the application of its immunity rule. The court, fully prepared to recognize North Carolina as

${ }^{108}$ Cf. M. Traynor, supra note 80 , at 865 .

${ }^{10 \tau} 258$ N.C. 609,129 S.E.2d 288 (1963). 
the only interested state, is suddenly confronted by the decision in Shaw v. Lee. Has not North Carolina renounced any interest in the application of its policy? Or has North Carolina simply never considered the matter in policy terms, having been befuddled by the traditional system of rules for choice of law? In either case, what should Virginia do? And what should State $F$, a disinterested forum, do if the action is brought there instead of in Virginia? Because I want to consider these questions further I relegate my tentative conclusion to the footnotes. ${ }^{108}$

\section{III}

\section{The Federal Court As Disinterested Forum}

There is some temptation to conclude that in the situation of the disinterested third state any technique of decision whatever, except coin-fipping and its analogues, is acceptable. My present conclusion, however, is that two techniques are to be preferred to all others in terms of reasonableness and safety: candid free choice between the competing policies and interests, amounting to the exercise of legislative discretion, and application of the law of the forum. If this position is sound, it follows that if the forum has no law of its own, the one acceptably reasonable and safe solution is free choice of the legislative type.

A forum with no law of its own is not such a paradox as it may at first seem. If a case like Kilberg were to be referred to arbitration the forum would owe allegiance to the law of neither state, nor to that of the state in which it sits. Prior to the decision in Erie R.R. v. Tompkins ${ }^{109}$ a federal court in a diversity case functioned very nearly as a forum with no law of its own. Purportedly it applied a general federal common law; but a court performing an essentially legislative function should be exercising delegated (or at least unexercised) legislative power. ${ }^{110}$ Since many subjects within the reach of the federal common law were beyond the ordinary powers of Congress, there was apparently no machinery for legislative revision of the common-law decisions of the courts. Conceivably, such a power of revision might have been found in the power of Congress, under the necessary and proper clause, ${ }^{111}$ to prescribe rules of decision for the federal courts; but that power seems not to have been part of our working philosophy, except in admiralty, either before or since the Erie decision.

Cavers (with Field and Mishkin) now proposes that in two limited classes of cases the federal court be authorized to function as disinterested forum, having no law of its own to apply but having freedom to choose the applicable state law without being bound by state rules for choice of law. ${ }^{112}$ The first class is composed of civil

\footnotetext{
${ }^{108}$ Virginia should apply the law of North Carolina. So should State $F$. What would be the result under $\$ 390 \mathrm{~g}$ of the Restatement Second?

${ }_{100} 304$ U.S. 64 (1938).

110 The premise of the reporters for the Study of Jurisdiction is "grounded upon the political axiom, advanced by Hamilton in justification of the federal judicial power, that judicial and legislative power should be coextensive." STUDY of JuRIsDiction 36 .

12 U.S. Const. art. I, $\$ 8$, cl. I8.

119 Stuny of Jurisdiction $\$ \$ 2344$ (c), 236I (c). Professor Cavers' discussion of choice-of-law thinking
} 
actions "in which the several defendants necessary for a just adjudication of the plaintiff's claim are not all amenable to process of any one territorial jurisdiction, and one of any two adverse parties is a citizen of a State and the other is a citizen or subject of another territorial jurisdiction."113 The second consists substantially of what are now interpleader cases cognizable by virtue of section 1335 of the Judicial Code. $^{114}$ In addition, Cavers and company propose statutory federal rules of choice of law for cases transferred under what are now sections I404(a) and I406(a) of the Judicial Code; ${ }^{115}$ and this proposal is worthy of brief notice though it touches the problem of the neutral forum only glancingly.

What is proposed is not some naive revival of the notion of a federal common law of conflict of laws. The basic approach is that the Klaxon ${ }^{116}$ doctrine, enforcing adherence to state rules for choice of law, is sound. The dispensation allowing independent federal choice of state law in these special cases is highly sophisticated. One can only hope that it is not so sophisticated that the average lawyer may be unable to appreciate the distinction, and may assume simply that there is to be a federal law of conflict of laws at least for these purposes. That is not the proposal as I understand it. The proposal is that for the special classes (indispensable-party and interpleader cases) a disinterested forum should be provided. Both classes consist of actions that, according to traditional conceptions, cannot be maintained in the courts of any state. When federal power to serve process anywhere in the country is invoked to permit maintenance of such cases in a federal court the basic principle underlying the Klaxon doctrine-that a state's power to determine the nature and scope of its domestic policy should not be impaired-must be deliberately limited. The court ceases to be simply another court of the state in which it sits; it becomes a "special substitute federal forum."117 In short, because of what is felt to be a pressing need for adjudication in a single court, for the purpose of reaching a result that cannot be reached in any state court, a federal forum is provided; the very purpose of that forum would be frustrated if there were adherence to the law of conflict of laws of the state in which the court sits; thus the court is to act as a disinterested forum, and as one, moreover, having no relevant internal law and policy of its own.

Reversing the order of discussion so far as these two classes of cases are concerned, let me say first that, on the basis of what has been said in the previous section of this paper as to the methods to be employed by the disinterested forum, I can accept with equanimity, and even with enthusiasm, this solution of the problem in interpleader cases. Application of the Klaxon rule in this class of cases

in this context is contained in id. at 154 . The views there stated are similar to those expressed in his contribution to this symposium, stupra 732. For a more accurate statement of the relative roles of the reporters and their consultant on conflict of laws see note 50 supra and Cavers, supra 732 n.x.

${ }^{213}$ STUDY OF JURISDICTION $\$ 2341$.

${ }^{114}$ Id. $\$ \$ 1335,2361$.

${ }^{115} I d . \$ \$ 1306,1307,1308$.

${ }^{110}$ Klaxon Co. v. Stentor Elect. Mfg. Co., 313 U.S. 487 (1941).

${ }^{217}$ STUDY OF JURISDICTION 72. 
creates a situation that is intolerable in theory if not in actual experience. When power to select the forum is lodged not in either of the adverse parties but in a stakeholder who is theoretically disinterested, but actually in excellent position to play games of collusion, mandatory determination of the case in accordance with the choice-of-law rules of the forum is indefensible. Yet so long as the only escape from that mode of determination was by way of a federal law of conflict of laws independent of state law it was as unavoidable as it was indefensible. Unless Erie and Klaxon were both wrong there could be no federal law of conflict of laws, independent of state law, for interstate cases; rightly understood, conflict of laws is a branch of domestic law-indeed, it is nothing more than the construction and interpretation of domestic law in the light of possibly conflicting foreign interests.

The Cavers solution of the dilemma is brilliant. Fully accepting the soundness of Erie and Klaxon and the proposition that there can be no higher federal law of conflict of laws, he argues (as I understand him): Grant that a federal court, simply by virtue of its federal character, has no greater power than a state court to subordinate the interest of one state to another; grant further that ordinarily, functioning as another court of the state in which it sits, the federal court must effectuate the interests of that state just as a state court would. It nevertheless happens that sometimes a state court must, of necessity, choose between the truly conflicting interests of two other co-ordinate states. This happens in the typical case of the disinterested third state. If a state court can do this sort of thing by necessity, so can a federal court. We need not claim for the federal court any superior status, any power to concoct a super-law of conflict of laws. There are certain situations that cry out for adjudication in a single court. No competent court exists, but the federal courts can be made competent by Congress. When provision is made by Congress for interstate interpleader, and such a case is accordingly filed in a federal court, the necessity for decision is every bit as great as it is in any disinterested-third-state situation in which the action cannot be dismissed consistently with justice. Abstention would mean double liability for an innocent party. Of necessity the federal court must decide; it can decide in the same way as a court of a disinterested third state.

Ideally the history of interpleader should have developed differently. The case that denied the power of a state court to bind the nonresident claimant in the interpleader situation was wrong when it was decided, and would probably not be followed today. ${ }^{118}$ Meanwhile, in response to that decision, federal interpleader has become established as the solution of the problem. However strongly one may feel that the better solution would have been to recognize the power of an interested state to reach the nonresident claimant by its process-a solution that would have avoided the uncomfortable phenomenon of the disinterested forum as now proposed-history is not easily reversed, and few would advocate abandonment of the historic solution. Interpleader is the case par excellence requiring adjudication in

${ }^{118}$ New York Life Ins. Co. v. Dunlevy, 24 I U.S. 518 (19I6); cf. Atkinson v. Superior Court, 49 Cal.2d 338, 316 P.2d 960 (1957), both discussed in Currie, op. cit. stupra note 3 , at 683-88. 
a single court. Almost certainly Congress originally contemplated freedom of decision in such cases, either by application of a general federal common law or by independent federal solution of conflict-of-laws problems. If that objective can be accomplished consistently with Erie and Klaxon by treating the federal court as a disinterested forum, as I believe it can, the solution is an admirable one.

In taking this view I assume that the federal court would function as I have suggested the court of the disinterested third state should function: it should frankly avow a purpose not to divine the governing law by pseudo-juridical reasoning but to put itself in the position of Congress and decide which interest Congress would subordinate if it were to consider the conflict from the point of view of the national interest. Although it may reasonably be argued that a federal court is in better position to make this kind of judgment than the courts of a disinterested third state, I am not at all sure that this is just what Cavers has in mind, and therein lies the source of such reservations as I have concerning his proposal as to interpleader. The statutory provision itself is neutral enough: "...the district court may make its own determination as to which State rule of decision is applicable."119 But Cavers assumes the federal courts would require precedents. ${ }^{120}$ This is not reassuring, since precedents would be of only incidental value in the process as I visualize it. He recognizes a danger in that the courts would be under pressure to employ entrenched mechanical rules, but hopes that instead they would be guided by "more meaningful criteria"121 of choice that have recently been recognized. To me this means analysis in terms of governmental interests, but that analysis is not helpful when interests are truly in conflict. His conception is clearest when he illustrates how the process of decision might operate, using for this purpose the familiar problem of married women's capacity to contract. ${ }^{22}$ The indicated choice on his hypothetical facts "would not require a judgment that that state's protective law was superior to, or 'weighed' more, than the other state's law. The decision would be based on a conclusion that the facts of the transaction should bring it within the reach of the state law protecting married women and beyond that of the state law protecting business concerns who deal with them."123

It is reassuring that the court will not be called upon to "weigh" the conflicting interests. ${ }^{124}$ But precisely what is meant by the statement that the decision would be based on a conclusion that "the facts of the transaction should bring it within the reach" of one state's law and "beyond the reach" of the other's? To me this must

${ }^{119}$ STUdY OF JuRISDICTION $\$ 236 \mathrm{r}(\mathrm{c})$.

${ }^{120}$ Id. at 183 . Mr. Cavers tells me that the cited discussion of what the federal courts would do if the Klaxon rule were abrogated entirely has no application to what they would do if it were abrogated only for the special cases under discussion. I accept this statement of his position, which, indeed, should perhaps have been gathered from his contribution to this symposium. See Cavers, supra 732. Irrespective of his assumptions or mine, however, there is danger that, given freedom to make their own choice of law, the federal courts will resort to precedent.

131 Id. at 186 .

${ }^{222}$ Id. at $163-64$.

${ }^{123} \mathrm{Id}$. at 164 .

194 It is not reassuring that the court is invited to invoke the question-begging formula referring to the intention of the parties. Ibid. 
mean one of two things: $(x)$ the laws of the respective states, though apparently in conflict, can reasonably be construed with such moderation as to avoid conflict (this seems to me to approximate Cavers' own technique in deciding the hypothetical case); or (2) if a legislative judgment were to be made as to which of the conflicting interests must yield on these facts, the most reasonable judgment would be to prefer the interest in protecting the married woman and subordinate the interest in protecting the business enterprise. But this is not what Cavers says.

Thus a brilliant solution to a dilemma seems marred by the dreary prospect that the federal courts, liberated from state laws of conflict of laws, will simply gravitate to mechanical rules or will lose us all in subjective judgments cast in pseudojuridical terms; we shall have escaped from "weighing" interests and from the "center of gravity," or the "proper law," only to find ourselves trying to determine whether the facts bring the case "within the reach" or "beyond the reach" of a particular state's law. This is as unconstructive as the basic solution is inspired. Consider the leading interpleader case, Griffin v. McCoach. ${ }^{125}$ I submit that it is perfectly clear how a federal court, liberated from the obligation to apply the law of the state in which it sits, should decide that case. It should decide in favor of the interest of New York in upholding the contract rights of the assignees and against the interest of Texas in protecting the lives of its citizens. It should do so for the plain reason that Congress, if it were to address itself to the problem, would almost certainly prescribe that solution. Texas was a minority of one in its "cynic fear" that a man took his life into his hands when he assigned a policy on his life to one having no insurable interest. From the national standpoint, laws facilitating commercial transactions are clearly to be preferred to such gloomy apprehensions of remote danger. The Texas law was bad law; the facts, except in so far as they must enter into any statement of these conclusions, have nothing to do with the matter.

Perhaps it is not politically possible to take the position that the federal court in the interpleader case should make the choice in terms of legislative discretion, even though it be clearly understood that all such decisions would be subject to the revisory power of Congress. But I am a law professor, not a politician; and I am unhappy about a political stratagem that will saddle the next generation of law students with the futility of trying to extract meaning from the pseudo-juridical mumbo jumbo that is employed to camouflage judicial legislation. ${ }^{128}$

\footnotetext{
${ }^{125} 313$ U.S. 498 (194I).
}

${ }^{120}$ Were it not for such portents, I should be tempted to suggest that the exemption from the Klaxon rule be broadened to include any federal court finding itself in the situation of the disinterested third state-e.g., the district court of Maryland in the LaChance case, supra note 54. The district court, though sitting as another court of Maryland, is quite as capable as the state court of making a choice of the legislative type, from the standpoint of the national interest, as is the disinterested state court. If the Erie-Klaxon doctrine is restricted to its essential meaning, that the district court is not to infringe the interests of the state in which it sits, this would be unobjectionable; and even if the doctrine is taken in its broadest meaning as proscribing a different result simply because the case is in the federal court, it will be in the highest degree unlikely that such differences in result can be predirted. By hypothesis the disinterested forum is a rare phenomenon. That a specific issue will arise 
Turning to the indispensable-party cases, I have these reservations and more. Cavers and I seem in agreement that the task of the disinterested forum is a peculiarly difficult one, and that it should not be deliberately thrust on a court except for very good reason. ${ }^{127}$ The urgency of the need in the interpleader case is established to my satisfaction; not so in the indispensable-party case. I am not an expert on the law of indispensable parties, and cannot become one pro hac vice. I have the impression, however, that courts are increasingly loath to refuse relief because of the absence of a party. ${ }^{128}$ It may be significant that the Study of Jurisdiction cites only one case-dating from 1855-to demonstrate the need for this extraordinary jurisdiction and this extraordinary function relative to choice of law. ${ }^{129}$ It is conceded that even in this case a just result could have been reached without extraordinary federal jurisdiction. ${ }^{130}$ Two law review articles are cited. Professor Reed seems to urge solution of the problem by a more sensible law of indispensable parties: "There is no person so intimately related to matter in litigation between others that there cannot be circumstances which will justify proceeding in his absence."131 Professor Hazard agrees and treats the problem as a false one-a "phantom."132 Apart from these considerations, which seem impressive though they are beyond my competence, my concern is that the unfortunate history of the interpleader jurisdiction not be repeated unnecessarily. This is not 1916. If the problem cannot be solved through improvement of the law of indispensable parties, it should probably be solved by utilizing modern conceptions of the power of an interested state to exercise jurisdiction over parties absent from the territory. At least that avenue ought to be explored before an exceptionally difficult task is foisted on the federal courts. The case for a disinterested federal forum in this instance has not, I think, been established.

\section{IV}

\section{The Law Applicable After Transfer}

There remains for discussion the solution proposed for the problem of the law to be applied after transfer of an ordinary diversity case to a district court in another state. I have been on both sides of this question, and can only hope that I have not

in such a context with sufficient frequency to apprise counsel that the result will differ as between state and federal courts seems a fanciful assumption.

127 "... [I]f the basic task of the courts in a choice-of-law case is not to apply broad jurisdictionselecting rules that ignore the content of the state laws chosen but rather to identify state policies and to determine the significance for those policies of their application or nonapplication in interstate situations, then the most appropriate forum for the performance of this task is a court of a state whose policies are in issue." STUDY OF JURISDiction 165 .

${ }^{128}$ See Keene v. Chambers, 27I N.Y. 326, 3 N.E.2d 443 (1936).

120 Shields v. Barrow, 58 U.S. (17 How.) 130 (1855).

${ }^{130}$ Study OF JURIsDiction 82 n.I 8.

${ }^{131}$ Reed, Compulsory Joinder of Parties in Civil Actions (pts. I and II), 55 MrcH. L. Rev. 327, 483, 538 (1957). As this is written the Advisory Committee on Civil Rules is preparing to recommend an amendment of Rule 19 of the Federal Rules of Civil Procdeure that should materially alleviate the problem.

${ }^{132}$ Hazard, Indispensable Party: The Historical Origin of a Procedural Phantom, 61 CouvM. L. Rev. 1254, 1288-89 (1961). 
been wrong more than once. ${ }^{133}$ Hence $I$ am awed by the confidence of those who would give their solution the relative permanence of congressional enactment. The proposed solution for transfers under what is now section I404(a) is at least original: if the motion for transfer is made by the defendant the law of the transferor state continues to be applied; ${ }^{134}$ if the motion is made by the plaintiff the law of the transferee state is applied instead. I confess that no such solution occurred to me in either of my previous studies of the problem. Beyond being original, this solution seems to me to have only the merit of being clever. It seems oddly at variance with a principle that is Cavers' own outstanding contribution to conflictof-laws thinking: that we should not employ jurisdiction-selecting rules that take no account of the content of the municipal laws to be applied. Unless there is some mandatory principle such as that of the Erie doctrine to be obeyed it would seem just as wrong to have jurisdiction-selecting rules for determining rules for choice of law. In either case the outcome cannot be foreseen. But it is not suggested that the Erie doctrine requires such a solution of the problem.

It seems to me that whether the law of the transferor state should be applied after transfer should depend among other things upon whether that state has an interest in its application. Consider the classic case of Headrick v. Atchison, Topeka \& Santa $F e R y .{ }^{135}$ At least if we assume that the limitation statute of the plaintiff's home state (Missouri) barred the action, as did the statute of California (where the injury occurred in the course of the foreign corporation's local business), New Mexico, the transferor forum, had not the slightest conceivable interest in giving the plaintiff the benefit of its longer time to sue. The only completely rational basis for applying New Mexico's law after transfer to California is that one does not like statutes of limitations, and desires to see cases determined on their merits. I have argued, not facetiously, that the application of the law of New Mexico in such a situation may be unconstitutional. ${ }^{136}$ In this I may be wrong, and certainly the courts faced with the problem have uniformly contrived in one way or another to avoid the bar of the statute. But it is one thing for the courts to muddle their way through the problem, resorting experimentally to humanitarian sentiments that may not ultimately survive analysis; it is quite another to enact into statute a rule of doubtful constitutionality, subversive of the declared policies of interested states. The weak

${ }^{133}$ Currie, Change of Ventse and the Conflict of Laws, 22 U. CHr. L. REv. 405 (I955); Currie, Change of Venue and the Conflict of Laws: $A$ Retraction, 27 id. 34 I (I960).

13. "To the extent that the court ordering the transfer would have been obliged under section 1652 of this title [the Rules of Decision Act] to apply the law of any State, including rules with respect to refusal to adjudicate the controversy and rules for selecting the applicable rule of decision, the court to which the action is transferred shall apply the law of that State..." STuDy OF JuRIsDiction \$ 1306 (c).

This formulation shrewdly avoids answering a question the Supreme Court has left unanswered: Is the federal court in a diversity case to follow the state law on forum non conveniens? On the assumption that the answer to that question might turn out to be yes, the direction that the law of the transferee state be applied seems incongruous. In my earlier studies of the problem I assumed, as did most commentators, that the forum non conveniens law of the state of original filing was a matter of some importance.

${ }^{135}$ I 82 F.2d 305 (Ioth Cir. 1950).

${ }^{130}$ Currie, Change of Venue and the Conflict of Laws: $A$ Retraction, 27 U. CHI. L. REv. 34I, 350-51 (1960). 
justification for thus allowing the plaintiff to retain the benefit of his choice of an inappropriate forum is that "the alternatives seem even more undesirable."137

Only one alternative is mentioned: a rule making the law of the transferee state applicable is judged undesirable because the decision on the issue of transfer might be decisive on the merits. ${ }^{138}$ Whatever may be the validity of this judgment, it ignores another alternative: the question of the law to be applied after transfer might be left to the courts for a while longer. There is hardly a crisis requiring its resolution by Congress. When I first studied the problem, seven years after the transfer provision was enacted, only four or five cases could be found in which it had been considered. Today, after another eight years, even the stimulus of Pearson v. Northeast Airlines, Inc., ${ }^{139}$ has resulted in only a slight flurry of motions to transfer in quest of a more favorable attitude toward choice of law. ${ }^{140}$ The American Law Institute invites serious trouble when it proposes statutory solution of a problem of interest mainly to law professors, especially when the courts, from the point of view of the Institute's own reporters, are doing a satisfactory job of deciding the rare cases that arise. ${ }^{141}$

Cavers approves the rule of proposed section 1306 (c) "although it may result now and then in the application of the choice-of-law rules of a disinterested forum (the transferor state)."142 To this extent I think the proposal is clearly wrong. The logic of the Cavers approach, exempting the court from the Klaxon requirement when it functions as a disinterested forum, would justify exemption in all such cases, not only those involving indispensable parties and interpleader; ${ }^{143}$ and the LaChance case ${ }^{144}$ seems to make it clear that when the original forum is both inconvenient and disinterested there is no reason why its law should be applied after transfer. The LaChance case also indicates the hollowness of the proposed ameliorative device whereby the transferor court will settle the applicable law for the transferee court prior to transfer: "The court in which the action is brought may make any appropriate ruling of law prior to the effective date of a transfer."110 Assume that Judge Thomsen had been disposed to grant the defendant's motion for transfer to North Carolina. We are to suppose that he will then sit down and figure out (without the benefit of Maryland cases in point) what the Maryland court, as disinterested forum, would decide as to the applicable law, and then make an order binding on the interested transferee forum in North Carolina. Why? Why not let the defendant take his chances with the interested forum to which he has asked

${ }^{137}$ STUDY OF JURISDICTION 66.

138 Ibid.

${ }^{180} 309$ F.2d 553 (2d. Cir. I962).

${ }_{1 * 0}$ E.g., Barrack v. Van Dusen, 309 F.2d 153 (3d Cir. 1963); Study of Jurisdiction 66, I93.

${ }^{161}$ Similar considerations seem applicable to the provision in proposed $\$ 1306(\mathrm{~b})$ for waiver of the statute of limitations when no available federal forum is deemed convenient and the consequence is dismissal (although only the term "stay" is used).

${ }^{142}$ Study OF JuRISDiction 195.

${ }^{143}$ See note 126 supra.

1" Note 54 supra.

${ }^{145}$ STUDY OF JURISDICTION $\$ 1306(\mathrm{c})$. 
transfer? It happens that Judge Thomsen's ruling would have pointed to application of North Carolina law, as we know; but suppose he were to decide otherwise: that the law of North Carolina should not be preferred-because, perhaps, of the modern Restatement doctrine that the state of domicile has the most significant relationship. Is there any reason why the federal court in North Carolina should be bound by such a ruling, even though it was the defendant who sought transfer to North Carolina? (It will be recalled that the effect of applying North Carolina law would be to give to the defendant the right he sought to implead the husband as a third-party defendant; the effect of applying the law of Maine would be to deny the defendant that right.)

I confess I cannot see where all this ends. We are discussing a problem of infinitesimal practical importance; a statutory remedy is proposed that would lead to fantastic complications. Surely the part of wisdom is to wait for the courts to gather more experience with the problem.

I am also skeptical of the wisdom of the rule proposed for the case in which it is the plaintiff who moves for transfer. ${ }^{146}$ First of all the proposal narrows the plaintiff's privilege as it now exists ${ }^{147}$ by permitting transfer only "upon a showing that it is justified by change of circumstances or by discovery of facts which the plaintiffs did not know at the time of the commencement of the action." Then it deprives the plaintiff of any benefit the law of the transferor forum might afford. One of the common reasons for a plaintiff's seeking transfer is that, perversely enough from the standpoint of draftsmen, he has filed his action in an inconvenient forum at a time when the action is barred by the law of that forum, though not by the law of the normal forum. ${ }^{148}$ Sometimes he wakes up in time to flle an independent action in the normal forum. If, however, the limitation period of the normal forum expires before he discovers his mistake, why should he not be allowed

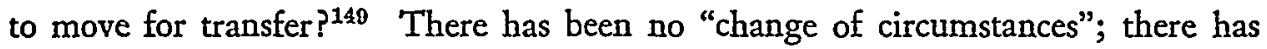
been no discovery of "facts" not known to the plaintiff when the action was commenced. Therefore, if language may be taken at its face value, his motion to transfer must be denied, and he cannot get to trial on the merits. It may be comforting for him to know that if transfer could be permitted on his motion the statute of limitations of the normal forum would apply, and his action might be treated as timely though filed in another state; but since he has no right to ask transfer the comfort is a bit cold. All this is rather odd since, by one possible hypothesis at least, the

${ }^{180}$ STUDY OF JuRisdiction $\$ 1307$ (b).

${ }^{147}$ Since interest is thus displayed in a restriction of the transfer privilege, it is somewhat surprising that there is no discussion of whether the transfer of actions removed from state courts is justified. Without intimating any conviction as to the proper answer, I suggest that this may be a more important matter for consideration than restriction of the plaintiff's privilege.

${ }^{148}$ See Currie, Change of Venue and the Conflict of Laws, 22 U. CHI. L. Rev. 405, 48x-82 (I955). Of seven cases cited (notes 180-82) one is most illustrative for present purposes though no motion for transfer was made under $\$$ I 404 (a): Riley v. Union Pacific R.R., I77 F.2d 673 (7th Cir. 1949).

I40 See Riley v. Union Pacific R.R., supra note I48. 
forum is not only inconvenient but may have no interest in the application of its shorter limitation period..$^{150}$

Cavers and his colleagues have great confidence in the ability of the federal courts to perform an essentially legislative function: choice between the truly conflicting interests of co-ordinate states. They have little confidence in the ability of the federal courts to perform what seems to be a function peculiarly appropriate for the judiciary: dealing on a case-by-case basis with a tricky problem, of less than crisis proportions, where generalizations are treacherous and factual configurations difficult to foresee. At the same time they have a healthy skepticism concerning the contribution that can be made to problems of choice of law generally by the legislative process. ${ }^{151}$ The consistency of the position would be improved if the attempt to regulate choice of law after transfer were abandoned.

It now seems appropriate for the American Law Institute, if it can, to reconcile the works of its left and right hands: the approach to choice of law taken by the reporters for the Study of Jurisdiction and that taken by the reporter for the Restatement Second.

\footnotetext{
${ }^{150}$ Even the provision as to the law applicable after transfer for improper venue ( $(\mathrm{r} 308(b))$ is not free from difficulty. While neither party can insist on retention of benefits afforded by the law of the improper forum, the plaintiff should be able to retain the benefit of the fact that his action was commenced on the day his complaint was filed. Thus if that date was within the period allowed by the transferee forum his case may be saved. The proposal does not preclude this possibility, but there is some danger that it may be obscured. This is especially so if we recall that there is a closely related problem not covered by the provision. Many claims based on federal law are subject to state statutes of limitations. In such a case the plaintiff has a very strong argument that his action was timely if it was filed, though in an improper forum, within the time allowed by the transferee forum. The draftsmen are covered on this point since the draft deals only with state law applicable under the Rules of Decision Act, and presumably that has nothing to do with application of state limitations to federal claims. For the sake of clarity and completeness, however, perhaps the problem should be dealt with if the Institute is to deal with the problem of state law applicable by virtue of the Rules of Decision Act and the Erie-Klaxon doctrine.

${ }^{151}$ STUDY OF JURISDICTION 202-05.
} 